\title{
MANAJEMEN MONETER DALAM MASA KRISIS
}

\author{
Doddy Zulverdi *
}

Krisis nilai tukar yang melanda Indonesia sejak pertengahan tahun 1997 telah berkembang menjadi krisis ekonomi akibat kerapuhan di sisi ekonomi mikro dan ketidaktepatan konbinasi kebijakan ekonomi makro. Permasalahan yang dihadapi dalam pemi lihan strategi kebijakan ekonomi makro adalah adanya konflik (tradeoff) antarkebijakan akibat sifat krisis yang multidimensional.

Kebijakan moneter sebagai salah satu elemen kebijakan ekonomi juga tidak terlepas dari kesulitan yang sama, yaitu dalam mengakomodasi berbagai sasaran kebijakan secara serentak. Kesulitan tersebut telah berlangsung sejak periode sebelum krisis dan berdampak negatif terhadap kondisi fundamental ekonomi makro yang berdasarkan hasil pengamatan temyata tidaklah sekuat yang diyakini semula.

Kesulitan yang dihadapi oleh otoritas baik dalam memilih maupun mengimplementasikan strategi kebijakan moneter juga dialami oleh berbagai negara yang pemah mengalami krisis serupa. Tidak ada satu strategi pun yang cocok diterapkan di semua situasi dan di semua negara. Pemilihan strategi yang tepat ditentukan oleh jenis tekanan ekstemal yang dihadapi, karakteristik struktur ekonomi, dan prioritas sasaran akhir yang dipilih. Berdasarkan kriteria tersebut dan mengingat masih rapuhnya sistem perbankan sebagai suatu jalur transmisi kebijakan moneter terpenting serta masih sangat rentannya perekonomian Indonesia terhadap tekanan-tekanan ekstemal, maka penerapan strategi jangkar inflasi di dalam suatu sistem nilai tukar yang agak fleksibel kiranya layak untuk dipertimbangkan secara mendalam.

Tulisan ini dibagi ke dalam lima bagian. Bagian pertama menjelaskan latar belakang pentingnya memilih strategi kebijakan moneter (temasuk kebijakan nilai tukar) yang tepat untuk membawa Indonesia keluar dari krisis ekonomi. Dalam bagian kedua diulas beberapa altematif strategi kebijakan ekonomi-moneter dari sisi teori. Selanjutnya, bagian ketiga membahas faktor-faktor yang memicu dan memperdalam krisis di Indonesia dan kebijakan yang telah diambil temasuk konflik yang dihadapi dalam penerapan strategi kebijakan moneter. Di bagian keempat, dengan mengacu kepada konsep teori dan pengalaman negara-negara lain serta pengalaman Indonesia sendiri, diajukan beberapa altematif strategi kebijakan moneter yang dapat diterapkan di Indonesia. Bagian kelima mengemukakan beberapa kesimpulan umum berikut rekomendasi kebijakan yang ditawarkan.

*) Doddy Zulverdi : Peneliti Ekonomi Junior, Bagian Analisis dan Perencanaan Kebijakan, UREM, BI

Penulis menyampaikan penghargaan yang tinggi kepada Erwin Haryono dan Wahyu Agung Nugroho, keduanya adalah Asisten Peneliti Ekonomi di Bagian APK, UREM-BI, atas bantuan riset yang diberikan dalam penyusunan tulisan ini. 
Pendahuluan

D) erbagai analisis menyimpulkan bahwa penyebab utama parahnya krisis di Asia adalah kerapuhan di sisi ekonomi mikro seperti sistem perbankan yang tidak sehat, ketergantungan sektor usaha pada hutang baik dari dalam maupun luar negeri (highly leveraged), dan sistem pasar yang dikuasai oleh segelintir monopolis yang menjadi kuat akibat praktek kolusi. ${ }^{1}$ Tidak sedikit yang menilai bahwa kondisi kerapuhan di sisi mikro tersebut kemudian diperburuk oleh ketidaktepatan kombinasi kebijakan ekonomi makro (policy mix) yang diambil pada awal dan selama krisis. ${ }^{2}$

Sebagai salah satu instrumen kebijakan ekonomi makro, kebijakan moneter memiliki peran yang sangat penting dalam penyelesaian krisis ekonomi yang sedang terjadi di Indonesia. Apalagi mengingat bahwa krisis ini telah berkembang menjadi fenomena yang dikenal sebagai financial distress, yaitu proses demonetisasi berupa penurunan permintaan akan likuiditas perekonomian (N2) sebagai akibat meningkatnya permintaan akan uang kartal. Apabila dibiarkan terus berlanjut, proses ini akan menimbulkan dampak negatif terhadap pertumbuhan ekonomi jangka panjang. Pemicu terjadinya fenomena flight to currency yang begitu tiba-tiba adalah ketidakpastian nilai tukar rupiah (McNelis, 1988). Oleh karena itu, upaya pemulihan ekonomi sangat tergantung kepada ketepatan strategi kebijakan moneter yang diambil, khususnya dalam rangka mengembalikan kepastian nilai tukar.

Tulisan ini bertujuan untuk menginventarisasi kemungkinan penyebab semakin parahnya krisis nilai tukar di Indonesia dilihat dari sisi kemungkinan ketidaktepatan kombinasi kebijakan moneter yang telah diambil selama ini. Dari hasil peninjauan ke belakang tersebut dan didukung oleh pengalaman negara-negara yang pernah atau sedang mengalami krisis yang mirip, diharapkan akan diperoleh gambaran arah kebijakan moneter dan nilai tukar yang tepat dalam mendukung proses pemulihan kegiatan ekonomi di masa datang. Dapat ditambahkan bahwa tulisan ini hanya membahas berbagai alternatif strategi kebijakan moneter di dalam suatu perekonomian yang terbuka (tidak ada pembatasan transaksi devisa).

\section{Alternatif Strategi Kebijakan di Masa Krisis: Tinjauan Teoritis}

Kebijakan moneter adalah salah satu elemen penting dari paket kebijakan ekonomi yang digunakan dalam mengatasi krisis ekonomi. Namun, efektivitas kebijakan moneter itu sendiri sangat tergantung kepada ketepatan dan keharmonisan pembagian tugas di

1 Lihat misalnya World Bank (1998) dan IMF (1998).

2 Lihat misalnya Radelet dan Sachs (1998). 
antara berbagai kebijakan yang tersedia. Oleh karena itu, bagian ini akan diawali dengan tinjauan singkat mengenai berbagai pilihan kebijakan yang terdapat di dalam paket tersebut. Selanjutnya, secara khusus akan dibahas peranan kebijakan moneter di dalam penyelesaian krisis disertai dengan alternatif strategi kebijakan moneter yang tersedia.

Pilihan Kebijakan dalam Menghadapi Tekanan Eksternal

Ada tiga jenjang pilihan kebijakan yang harus diputuskan oleh pemerintah dalam menghadapi tekanan-tekanan eksternal (Krugman, 1995), yaitu:

- Apakah tekanan-tekanan eksternal tersebut harus dihadapi melalui kebijakan financing (yaitu dengan meminjam dana dari luar negeri untuk menutupi penurunan penerimaan ekspor dan kenaikan biaya impor/biaya bunga) atau melalui kebijakan adjustment (yaitu dengan melakukan berbagai penyesuaian dalam rangka mendorong ekspor dan mengurangi impor) .

- Seandainya pilihan jatuh kepada kebijakan adjustment, seberapa besar bobot penyesuaian perlu dibebankan masing-masing kepada strategi pengurangan pengeluaran (expenditure reducing policy) dan strategi pengalihan pengeluaran (expenditure switching policy).

- Akhirnya, alternatif mana yang akan dipilih di antara dua pilihan strategi kebijakan pengalihan pengeluaran, yaitu antara kebijakan devaluasi dan kebijakan perdagangan.

Kebijakan financing akan diambil apabila tekanan-tekanan yang terjadi diyakini hanya bersifat temporer dan dapat diatasi dengan menggunakan dana luar negeri dalam jumlah yang minimal. Sebaliknya, apabila tekanan-tekanan tersebut lebih bersifat jangka panjang maka harus dilakukan kebijakan adjustment. Namun, terdapat beberapa kondisi yang seringkali mendorong otoritas untuk menerapkan kedua kebijakan secara bersama-sama, yaitu:

- Tekanan-tekanan sosial politik seringkali menghalangi otoritas dalam melakukan penyesuaian-penyesuaian secara maksimal sehingga mau tidak mau harus dibantu dengan kebijakan financing. Hal ini karena kebijakan penyesuaian mengandung berbagai pilihan yang tidak menyenangkan seperti kenaikan pajak/penurunan subsidi, pengurangan konsumsi, dan sebagainya.

- Sulitnya membedakan antara tekanan-tekanan yang bersifat temporer dan permanen menyebabkan otoritas seringkali memutuskan untuk menerapkan kedua kebijakan secara bersamaan untuk menghindari resiko salah pilih.

- Dampak dari kebijakan penyesuaian biasanya baru dirasakan secara efektif setelah periode yang relatif panjang. Oleh karena itu, penggunaan sumber dana luar negeri 
seringkali diperlukan untuk mengurangi dampak negatif jangka pendek dari krisis yang terjadi sambil menunggu hasil dari kebijakan penyesuaian.

- Negara yang mengalami krisis seringkali mengalami kesulitan untuk memperoleh dana luar negeri, terutama dari pihak swasta, dalam jumlah yang memadai karena adanya krisis kepercayaan. Oleh karena itu, otoritas tidak dapat semata-mata menggantungkan diri kepada kebijakan financing .

Kebijakan pengurangan pengeluaran bertujuan untuk mengurangi pengeluaran oleh penduduk suatu negara sehingga mengurangi tekanan terhadap neraca pembayaran, nilai tukar, dan laju inflasi. Terdapat tiga cara yang dapat diambil otoritas untuk mengurangi pengeluaran nasional, yaitu:

- Mengurangi pengeluaran pemerintah.

- Mengurangi pengeluaran masyarakat melalui peningkatan pajak atau pemotongan subsidi.

- Membatasi hutang sektor swasta melalui pembatasan pemberian kredit oleh sistem perbankan (kebijakan ini berada di dalam ruang lingkup kebijakan moneter) .

Sementara itu, kebijakan pengalihan pengeluaran bertujuan untuk memperbaiki transaksi berjalan dengan cara mengalihkan pengeluaran masyarakat dari produk impor ke produk dalam negeri dan mendorong peningkatan ekspor. Terdapat dua instrumen utama yang dapat diterapkan oleh pemerintah untuk mengalihkan pengeluaran nasional, yaitu: devaluasi dan kebijakan perdagangan (perubahan tarif, pemberlakuan kuota, dan subsidi ekspor). Berbeda dengan kebijakan pengurangan pengeluaran, kebijakan pengalihan pengeluaran tidak secara langsung memaksa masyarakat untuk menurunkan pengeluarannya sehingga resiko kontraksi ekonomi dapat diminimalkan. Namun, kelemahan utama kebijakan pengalihan pengeluaran adalah cenderung mendorong kenaikan laju inflasi. Hal ini terjadi karena apabila perekonomian sudah berada pada tingkat penggunaan kapasitas penuh maka kenaikan permintaan domestik dan permintaan ekspor akan menimbulkan tekanan kenaikan harga-harga di dalam negeri. Kalau pun perekonomian masih berada di bawah kapasitas penuh, tekanan inflasi masih tetap akan timbul dalam bentuk imported inflation akibat depresiasi/devaluasi nilai tukar.

Mengingat berbagai kelebihan dan kelemahan yang terkandung di dalam masingmasing kebijakan, berbagai negara seringkali menerapkan kombinasi kebijakan pengurangan dan pengalihan pengeluaran. Namun, karena begitu besarnya faktor ketidakpastian di dalam suatu perekonomian yang sedang mengalami krisis dan sangat tingginya tekanan imported inflation (akibat devaluasi/depresiasi), pemerintah seringkali terpaksa menerapkan kebijakan pengurangan pengeluaran secara drastis. Akibatnya, 
minimal dalam jangka pendek, negara-negara tersebut mengalami fenomena stagflasi, yaitu tingginya laju inflasi yang diiringi oleh resesi ekonomi.

Selanjutnya, di antara dua instrumen kebijakan pengalihan pengeluaran, pilihan yang diambil akan sangat tergantung kepada efisiensi birokrasi dan dukungan politik yang diberikan masyarakat kepada pemerintah. Kebijakan devaluasi memiliki keunggulan daripada kebijakan perdagangan karena tidak membutuhkan administrasi dan birokrasi yang rumit. Sebaliknya, kebijakan devaluasi memiliki kelemahan karena menimbulkan pergeseran distribusi pendapatan yang seringkali secara politik tidak menguntungkan bagi keberhasilan kebijakan tersebut.

\section{Alternatif Strategi Kebijakan Moneter}

Dari serangkaian pilihan kebijakan yang harus diambil oleh pemerintah dalam mencoba mengatasi tekanan-tekanan eksternal, terlihat bahwa kebijakan moneter dan nilai tukar memiliki peran penting dalam penerapan kebijakan penyesuaian (adjustment) Kebijakan moneter adalah salah satu instrumen kebijakan pengurangan pengeluaran sedangkan kebijakan nilai tukar adalah salah satu instrumen kebijakan pengalihan pengeluaran. Untuk itu, berikut ini akan diulas berbagai pilihan strategi kebijakan maupun kombinasi kebijakan yang dapat diambil oleh otoritas dalam menerapkan kebijakan moneter dan nilai tukar.

William Poole (1970) mengidentifikasi tiga altematif strategi kebijakan moneter, yaitu: strategi jangkar uang beredar (money stock targeting), strategi jangkar suku bunga (interest rate targeting), dan strategi kombinasi sistematis antara sasaran volume uang beredar dan tingkat suku bunga. Ketiga strategi tersebut lebih relevan diterapkan di dalam suatu perekonomian tertutup (derajat mobilitas modal rendah) atau di dalam suatu perekonomian terbuka yang menerapkan kebijakan nilai tukar mengambang karena hanya di dalam kedua bentuk perekonomian tersebut otoritas moneter memiliki independensi penuh dalam mengendalikan jumlah uang beredar dan/atau suku bunga domestik.

Dengan menggunakan kerangka model IS-LM, Poole menunjukkan bahwa di antara cua pilihan ekstrim: jangkar uang beredar dan jangkar suku bunga, strategi yang tepat tergantung kepada jenis tekanan ekonomi makro yang terjadi. Apabila suatu perekonomian mengalami tekanan-tekanan riil (real shocks) sehingga kurva IS mengalami pergeseran maka strategi jangkar uang beredar adalah pilihan yang lebih tepat karena perubahan suku bunga (bagi perekonomian tertutup) atau perubahan nilai tukar (bagi perekonomian terbuka) akan meredam tekanan-tekanan tersebut dan meminimalkan dampak negatifnya terhadap stabilitas harga atau produksi. Sebaliknya, apabila yang terjadi adalah tekanan-tekanan moneter (monetary shocks) yang menggeser 
kurva LM maka yang lebih tepat adalah strategi jangkar suku bunga karena perubahan uang beredar atau neraca pembayaran akan meredam tekanan-tekanan tersebut dan meminimalkan dampak negatifnya terhadap stabilitas harga atau produksi.

Grafik 1 mengilustrasikan suatu perekonomian sedang mengalami tekanan-tekanan riil yang bersifat random sehingga kurva IS bergeser di antara $\mathrm{IS}_{1}$ dan $\mathrm{IS}_{2}{ }^{3}$. Dengan asumsi fungsi permintaan uang stabil, jika jumlah uang beredar dikendalikan pada level $\mathrm{M}^{\star}$ (strategi jangkar uang beredar) maka kurva LM yang terjadi adalah IM dan tingkat produksi/pendapatan akan berada di antara $Y_{1}$ dan $Y_{2}$. Namun, apabila suku bunga dikendalikan pada tingkat $r^{\star}$ (strategi jangkar suku bunga) maka kurva IM yang terjadi adalah $\mathrm{LM}_{2}$ dan tingkat produksi/pendapatan dapat berada di antara $\mathrm{Y}_{0}$ dan $\mathrm{Y}_{3}$, suatu rentang yang lebih lebar daripada antara $Y_{1}$ dan $Y_{2}$. Dalam hal ini, strategi jangkar uang beredar adalah pilihan yang lebih tepat karena dapat lebih meminimalkan dampak negatif tekanan riil terhadap stabilitas produksi/pendapatan.

Grafik 2 menggambarkan suatu perekonomian sedang mengalami tekanan permintaan uang yang bersifat random. Apabila jumlah uang beredar dikendalikan pada level $M^{\star}$ maka kurva $\mathbf{L M}$ akan bergerak antara $\mathrm{LM}_{1}$ dan $\mathrm{LM}_{2}$ dan tingkat produksi akan berada di antara $Y_{1}$ dan $Y_{2}$. Sebaliknya, apabila suku bunga dipertahankan pada tingkat $r^{*}$, kurva IM dan tingkat produksi yang terjadi masing-masing adalah $\mathrm{LM}_{3}$ dan $\mathrm{Y}_{\mathrm{f}}$ (tingkat

Grafik 1

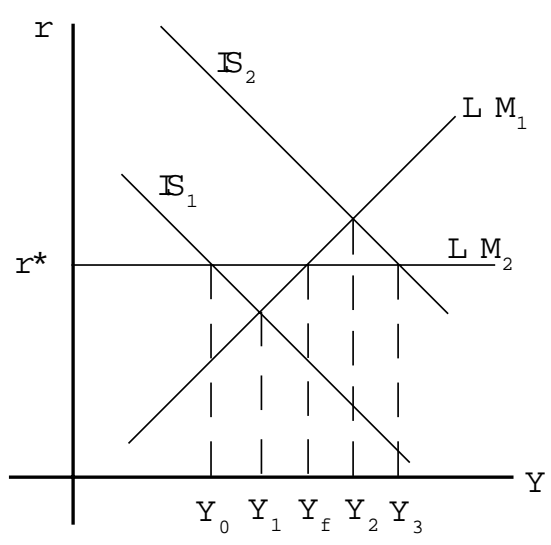

Grafik 2

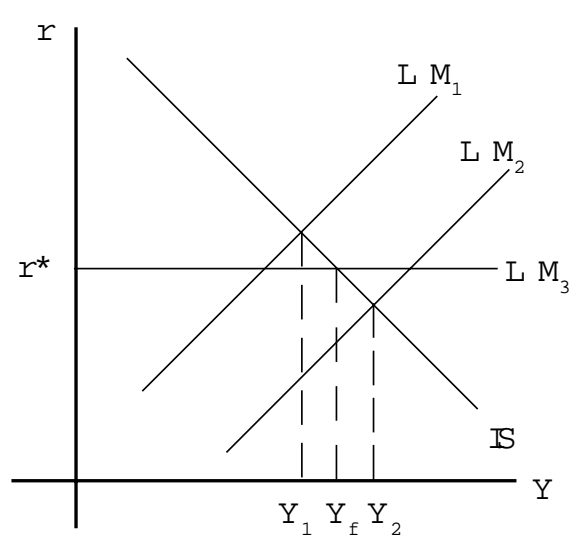

3 Poole (1970, hal. 200) mengasumsikan tingkat harga konstan sehingga strategi kebijakan yang diambil diarahkan untuk mencapai sasaran stabilitas produksi pada tingkat full employment. Secara implisit, hal ini juga berarti bahwa sasaran yang dituju adalah stabilitas harga karena dengan mengupayakan perekonomian selalu berproduksi pada tingkat full employment berarti mengurangi tekanan perubahan harga-harga. 
produksi/pendapatan full employment). Dengan demikian, strategi yang lebih tepat adalah strategi jangkar suku bunga.

Sebagaimana terlihat pada Grafik 1, strategi jangkar uang beredar dapat dibuat lebih optimal dengan mengubah elastisitas kurva LM terhadap perubahan suku bunga. Perubahan elastisitas tersebut dapat dilakukan dengan membuat suplai uang beredar sensitif terhadap suku bunga. Secara sederhana, hal ini dapat diilustrasikan oleh sistem persamaan deterministik berikut.
(1) $M$
$=a_{0}+a_{1} \cdot Y+a_{2} r$
(Kurva LM)
(2) $\mathrm{M}^{\mathrm{s}} \quad=\mathrm{b}_{1}+\mathrm{b}_{2} \mathrm{r}$
(Suplai uang yang sensitif terhadap suku bunga)

Substitusikan persamaan (2) ke dalam persamaan (1) :

$$
\begin{array}{ll}
\Leftrightarrow b_{1}+b_{2} r & =a_{0}+a_{1} \cdot Y+a_{2} r \\
\Leftrightarrow a_{1} \cdot Y & =b_{1}-a_{0}+\left(b_{2}-a_{2}\right) x \\
\Leftrightarrow Y & =\left(b_{1}-a_{0}\right) / a_{1}+\left(b_{2}-a_{2}\right) / a_{1} r
\end{array}
$$

Persamaan yang terakhir adalah kurva IM dengan suplai uang sensitif terhadap suku bunga. Koefisien variabel $r$, yaitu $\left(\mathrm{b}_{2}-\mathrm{a}_{2}\right) / \mathrm{a} 1$, adalah elastisitas kurva IM terhadap suku bunga. Elastisitas tersebut tergantung kepada elastisitas pemintaan uang terhadap suku bunga $\left(a_{2}\right)$, elastisitas suplai uang terhadap suku bunga $\left(b_{2}\right)$, dan suatu konstanta $\left(a_{1}\right)$. Karena elastisitas permintaan uang terhadap suku bunga $\left(a_{2}\right)$ tidak berada dalam kendali otoritas moneter maka upaya mengubah elastisitas kurva IM hanya dapat dilakukan dengan mengubah elastisitas suplai uang terhadap suku bunga $\left(\mathrm{b}_{2}\right)$. Dengan perkataan lain, kebijakan moneter yang lebih optimal dapat diperoleh dengan menerapkan strategi di mana sasaran jumlah uang beredar dan sasaran suku bunga ditetapkan berdasarkan suatu hubungan tertentu (dalam hal ini, hubungan tersebut dikuantifikasi dalam bentuk kofisien $\mathrm{b}_{2}$ )

Sekalipun strategi kombinasi tersebut secara teoritis dapat menghasilkan kebijakan yang lebih optimal, dalam praktek tidak selalu demikian. Alasannya, otoritas moneter dituntut mengetahui lebih banyak parameter daripada yang dituntut oleh strategi jangkar uang beredar maupun jangkar suku bunga (Poole, hal. 209). Di dalam situasi yang masih diliputi oleh ketidakpastian, semakin banyak parameter yang harus diestimasi, semakin tinggi resiko kegagalan strategi yang dipilih.

Di samping ketiga altematif strategi di atas, terdapat dua pilihan strategi lain, yaitu strategi jangkar nilai tukar dan jangkar laju inflasi (inflation targeting) (Houben, 1997) . Sebagaimana halnya strategi jangkar suku bunga, strategi jangkar nilai tukar lebih cocok diterapkan pada perekonomian yang mengalami tekanan-tekanan moneter khususnya 
dalam bentuk fluktuasi permintaan uang. Dalam hal ini, tekanan-tekanan tersebut akan diredam oleh penyesuaian yang terjadi pada neraca pembayaran sehingga dampak negatifnya terhadap stabilitas harga dan produksi dapat diminimalkan.

Alternatif strategi jangkar laju inflasi terutama tepat untuk diterapkan di dalam perekonomian yang mengalami tekanan-tekanan besar baik moneter maupun riil pada saat bersamaan. Keunggulan utama strategi ini terletak pada kemampuannya untuk secara langsung mempengaruhi ekspektasi inflasi dan pada saat yang sama tetap memberikan keleluasaan kepada otoritas dalam menyusun respons yang tepat terhadap berbagai tekanan yang melanda perekonomian.

\section{Kondisi Indonesia Sebelum dan Selama Masa Krisis}

\section{Penyebab Krisis yang Melanda Indonesia}

Tekanan-tekanan eksternal dapat mempengaruhi perekonomian suatu negara melalui dua jalur utama, yaitu pasar barang internasional dan pasar keuangan internasional. Tekanan-tekanan yang berasal dari pasar barang internasional dapat berbentuk penurunan permintaan ekspor atau gangguan suplai barang impor. Sedangkan tekanan yang berasal dari pasar keuangan internasional dapat berbentuk kenaikan suku bunga riil internasional dan terputusnya akses ke pasar keuangan internasional akibat anjloknya kepercayaan investor. Untuk kasus Indonesia, faktor yang disebutkan terakhir tampaknya lebih relevan dalam menjelaskan penyebab krisis yang terjadi. Yang kemudian sering menjadi bahan perdebatan adalah penyebab dari hilangnya kepercayaan tersebut.

Secara ekstrim terdapat dua pendapat mengenai penyebab hilangnya kepercayaan investor terhadap Indonesia. Pendapat pertama meyakini bahwa kerapuhan sistem keuangan internasional telah membuat berbagai negara sangat rentan terhadap contagion effect (Radelet dan Sachs, 1998). Oleh karena itu, menurut kubu ini jalan keluarnya adalah dengan memperketat rambu-rambu yang mengatur bekerjanya sistem keuangan internasional serta meredifinisi peran dan tugas lembaga-lembaga Bretton-Woods agar lebih mampu mengemban misi utamanya sebagai penjaga stabilitas sistem moneter internasional. Sebaliknya, pendapat kedua meyakini bahwa kelemahan internal seperti kerapuhan sistem perbankan, sistem pasar yang monopolistik, dan ketidaktepatan kebijakan makro adalah faktor utama hilangnya kepercayaan investor.

Faktor ketidaktepatan kebijakan ekonomi makro agaknya bertentangan dengan keyakinan kita dan berbagai lembaga keuangan internasional selama ini bahwa fundamental ekonomi Indonesia sangat kuat karena didukung oleh kebijakan ekonomi makro yang 
berhati-hati. Pertanyaannya adalah: apakah indikator-indikator ekonomi makro sebelum krisis memang bergerak normal dan tidak mengindikasikan kemungkinan timbulnya krisis?

Indikator Krisis dari Sisi Ekonomi Makro

Berdasarkan hasil studi Kaminsky-Reinhart (1996) dan Kaminsky (1998) terhadap 102 krisis keuangan yang terjadi di 20 negara, terdapat beberapa indikator ekonomi makro dan keuangan yang mampu memberikan peringatan secara dini akan kemungkinan timbulnya krisis. Dengan menggunakan indikator-indikator tersebut terlihat adanya indikasi peningkatan kerentanan ekonomi Indonesia terhadap tekanan-tekanan eksternal. Dengan perkataan lain, kondisi fundamental ekonomi makro Indonesia dalam periode sebelum krisis tidaklah sekuat yang diduga semula.

Berikut ini adalah gambaran beberapa indikator moneter dan keuangan yang mengindikasikan adanya peningkatan tekanan bubble economy dan masalah perbankan terutama sejak tahun 1996 (lihat Panel 1):

- Pertumbuhan tahunan multiplier M2 kembali meningkat sejak awal tahun 1996 dan terus menunjukkan pertumbuhan positif hingga awal tahun 1997 setelah mengalami perlambatan secara tajam sejak tahun 1990. Pertumbuhan positif multiplier MD telah meningkatkan kemampuan perbankan dalam menciptakan uang.

- Rasio kredit terhadap PDB yang terus bergerak naik sejak akhir 1994, menunjukkan kenaikan yang semakin cepat sejak akhir 1996.

- Rasio suku bunga kredit terhadap deposito (terutama deposito 1 bulan) cenderung meningkat sejak pertengahan 1995 hingga pertengahan 1997. Hal ini kemungkinan mencerminkan penurunan kualitas kredit perbankan. Dalam situasi ini, perbankan akan terpaksa menaikkan suku bunga kredit melebihi kenaikan suku bunga simpanan untuk menutupi kerugian atau potensi kerugian yang berasal dari kredit macet.

- Sejak pertengahan tahun 1996 terdapat kecenderungan peningkatan pertumbuhan simpanan valas. Sebaliknya, pertumbuhan simpanan rupiah cenderung mengalami penurunan. Hal ini mengindikasikan adanya peningkatan ekspektasi depresiasi rupiah di masyarakat.

- Sejak pertengahan tahun 1996 terjadi "excess supply" Ml riil. Kondisi ini dapat disebabkan oleh penciptaan uang yang berlebihan akibat ekspansi perbankan yang tidak berhati-hati atau dapat pula disebabkan oleh lebih rendahya pemintaan riil daripada suplai akibat meningkatnya ekspektasi inflasi dan depresiasi. 


\section{Panel 1}
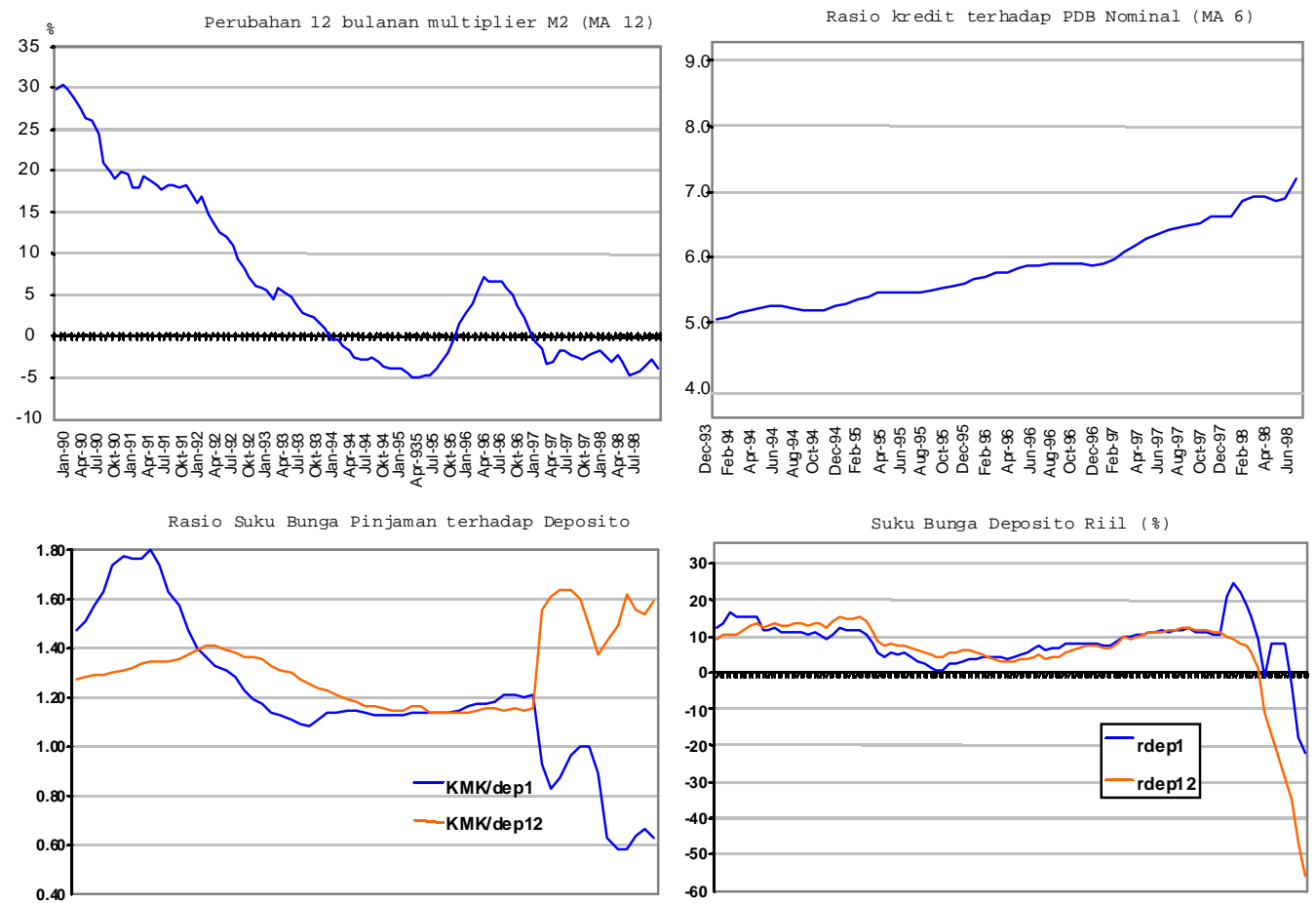

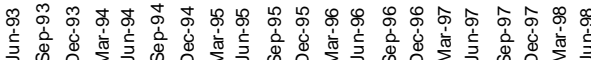
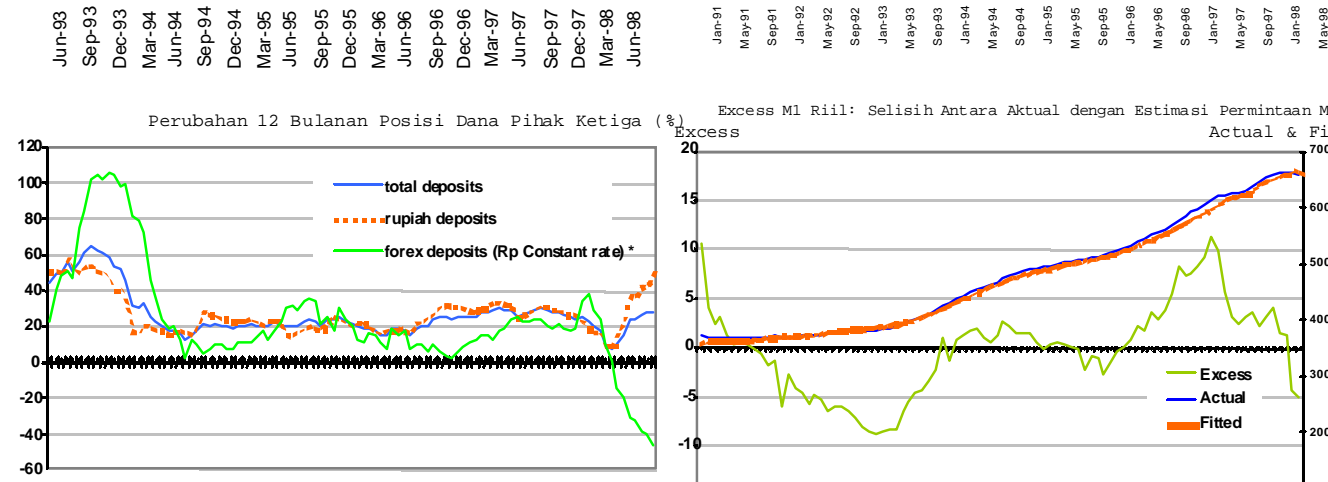

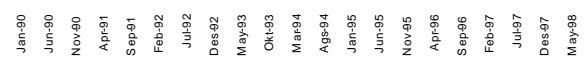

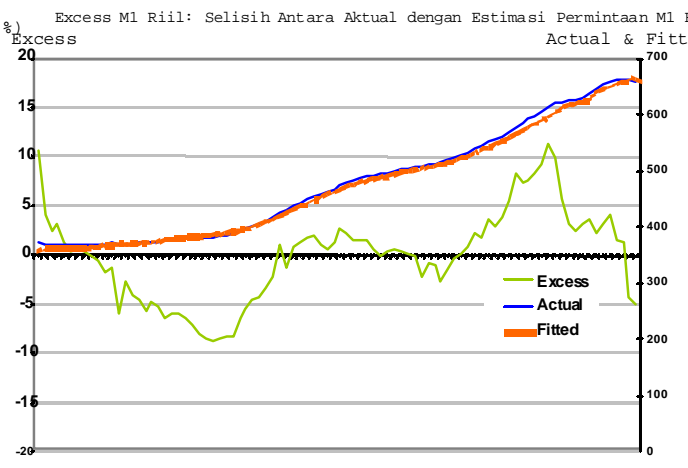

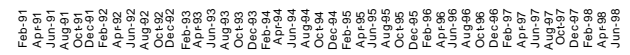


Beberapa indikator eksternal berikut juga memberikan indikasi semakin rentannya ekonomi Indonesia terhadap tekanan-tekanan eksternal (lihat Panel 2) :

- Pertumbuhan ekspor nonmigas menunjukkan kecenderungan menurun sejak pertengahan tahun 1995. Melambatnya pertumbuhan ekspor tersebut terkait dengan penguatan (apresiasi) nilai tukar riil sejak akhir tahun 1992, yaitu tahun dimulainya penerapan sistem nilai tukar crawling peg. Dalam periode tersebut terdapat indikasi kuat bahwa nilai tukar rupiah cenderung mengalami overvalued seperti diperlihatkan oleh semakin melebarnya selisih antara nilai tukar aktual dengan trend-nya.

- Meskipun nilai tukar riil mengalami apresiasi dan overvalued, pertumbuhan impor nonmigas justru cenderung menurun sejak akhir tahun 1995. Sebagaimana akan dijelaskan berikut ini, melambatnya pertumbuhan impor nonmigas diperkirakan terkait dengan melambatnya pertumbuhan ekonomi.

Berikut ini adalah gambaran beberapa indikator sektor riil dalam periode sebelum dan selama krisis (lihat Panel 2):

- Setelah sempat mengalami lonjakan cukup tinggi dalam tahun 1994, pertumbuhan ekonomi menunjukkan trend menurun sejak pertengahan 1995. Selanjutnya, sejak triwulan terakhir 1997 pertumbuhan ekonomi menurun sangat tajam.

- Agak sulit untuk memperoleh gambaran konklusif dari perkembangan indeks harga saham gabungan (IHSG) di Bursa Efek Jakarta. Dilihat dari trend jangka panjang, IHSG menunjukkan pertumbuhan yang cenderung menurun sejak awal tahun 1990. Namun, perkembangan sejak awal 1996 hingga terjadinya krisis rupiah pada bulan Juli-Agustus 1997 memperlihatkan pertumbuhan yang cenderung meningkat. Kecenderungan peningkatan harga saham di tengah kecenderungan melambatnya pertumbuhan ekonomi menunjukkan kuatnya tekanan spekulatif selama periode sebelum krisis.

Kebijakan yang Telah Diambil

Pertanyaan lanjutan adalah: Kebijakan apa yang telah diambil oleh pemerintah untuk meredam tekanan spekulatif dan sejauh mana efektivitasnya? Di samping itu, mengingat besarnya kemungkinan timbulnya konflik antarkebijakan dalam mencapai berbagai sasaran sehingga selalu terdapat resiko ketidaktepatan kombinasi kebijakan yang diambil maka satu pertanyaan lain juga relevan untuk diajukan, yaitu: Sejauh mana kemungkinan kombinasi kebijakan yang telah diambil, baik sebelum maupun selama krisis, justru menambah tekanan spekulatif dan mempersulit penyelesaian krisis? 


\section{Panel 2}

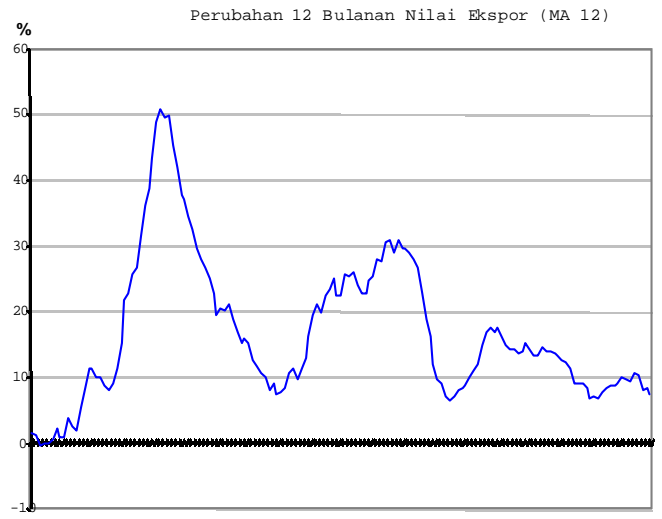

Indeks Nilai Tukar Riil Bilateral (Rp terhadap US\$, Juni
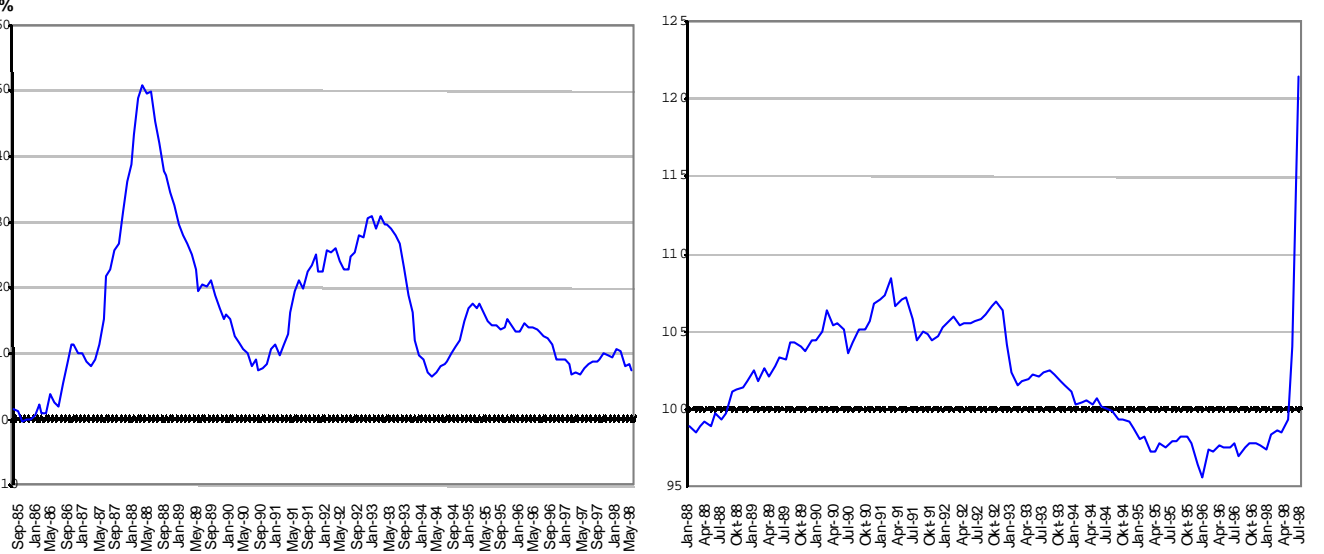

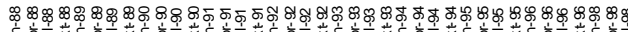

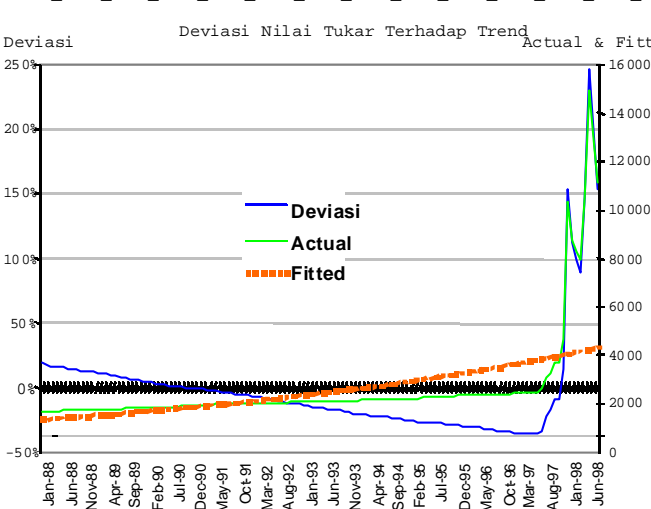

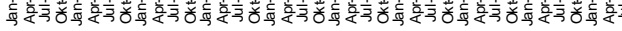
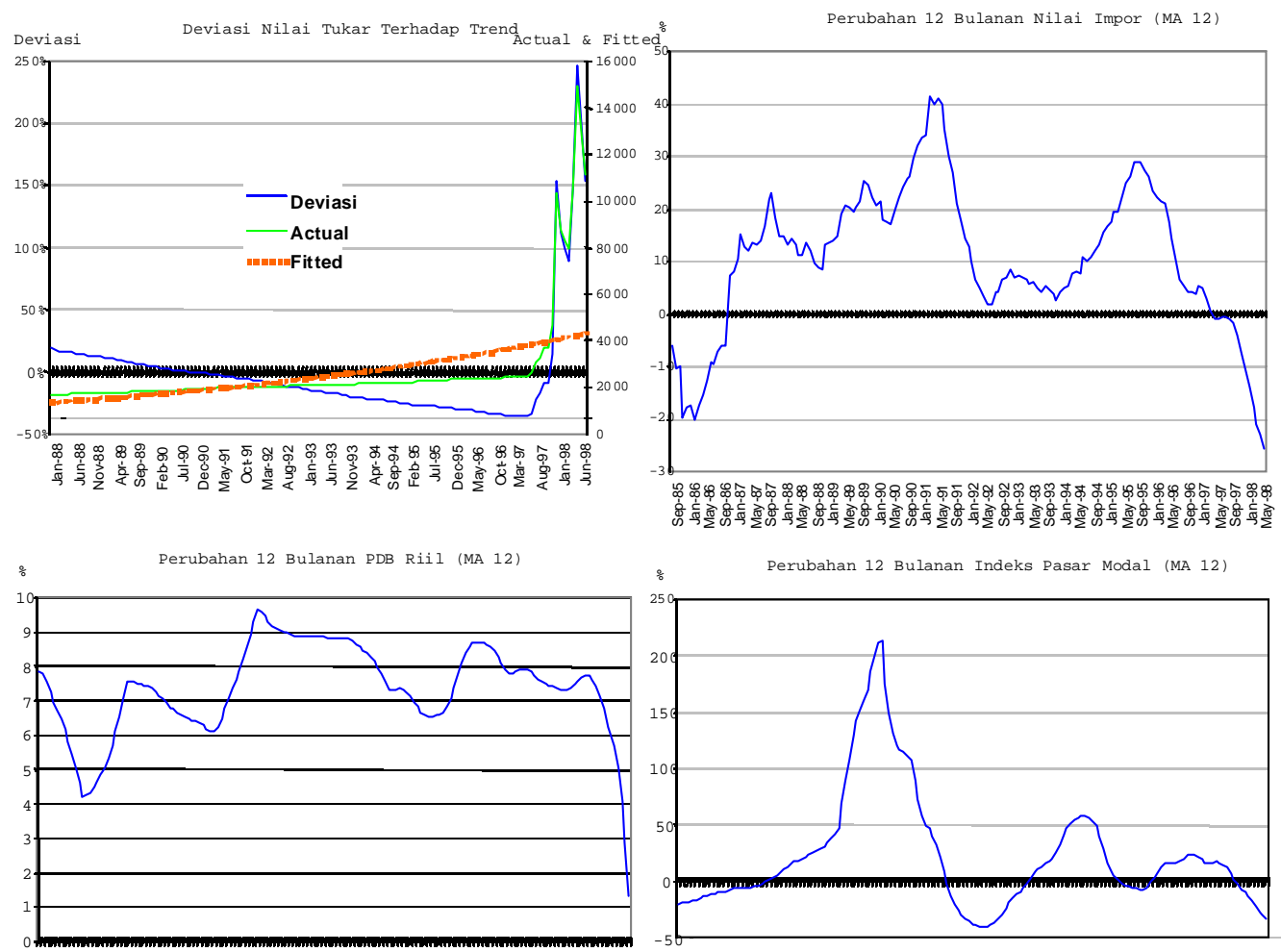

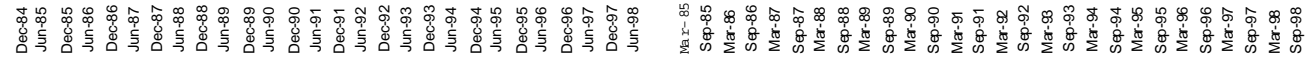


Kebijakan Pra-Krisis

Otoritas moneter sudah lama menyadari resiko yang terkandung di dalam arus modal masuk yang terlampau deras, terutama yang berjangka pendek, terhadap perekonomian Indonesia. Upaya-upaya untuk menghambat derasnya arus modal jangka pendek telah banyak dilakukan, seperti: melebarkan rentang intervensi nilai tukar, menaikkan giro wajib minimum, dan membatasi ekspansi kredit perbankan ke sektor properti. Namun, upaya-upaya tersebut tampaknya tidak memberikan hasil yang memadai. Bahkan, sebagaimana tercermin pada berbagai indikator di atas, pasar seolah-olah mengesampingkan gejala melemahnya kondisi fundamental ekonomi makro serta mengabaikan peringatan yang terkandung di dalam berbagai kebijakan pemerintah.

Terdapat beberapa kemungkinan penyebab kurang efektifnya kebijakan-kebijakan yang telah diambil oleh otoritas moneter dalam meredam tekanan-tekanan spekulatif, yaitu:

A. Sentimen positif terhadap prospek emerging markets, termasuk Indonesia, selama periode pra-krisis masih terlalu kuat dibandingkan dengan intensitas kebijakan yang diarahkan untuk membendung derasnya arus masuk modal. Kebijakan yang diterapkan dengan "dosis" yang tidak tepat justru dapat menimbulkan efek negatif. Hal ini diperlihatkan oleh ketidakberhasilan kebijakan pelebaran rentang intervensi dalam meredam arus masuk modal spekulatif. Dalam kondisi masih kuatnya sentimen positif terhadap ekonomi Indonesia, pelebaran rentang intervensi justru memberikan ruang gerak bagi penguatan (apresiasi) nilai rupiah (lihat grafik Perkembangan Rentang Intervensi dan Nilai Tukar Rp/US\$) * Apresiasi nilai tukar riil secara perlahan-lahan menggerogoti daya saing perekonomian domestik sehingga memperlemah kondisi fundamental ekonomi makro. Kondisi ini juga menunjukkan bahwa penggunaan satu instrumen kebijakan (dalam hal ini kebijakan nilai tukar) untuk mencapai lebih dari satu sasaran (yaitu mempertahankan daya saing produk dalam negeri sekaligus menghambat arus modal spekulatif) dapat berakhir pada kegagalan dalam mencapai semua sasaran.

B. Kebijakan yang diarahkan untuk meredam tekanan spekulatif ketika sentimen pasar sudah berbalik arah menjadi negatif justru telah semakin memperparah sentimen negatif tersebut. Kebijakan pelebaran rentang intervensi terakhir tanggal 11 Juli 1997 yang dilakukan sebagai respons terhadap krisis nilai tukar di Thailand diperkirakan telah memberikan sinyal kepada para spekulan akan ketidaksiapan/ketidaksediaan otoritas moneter dalam mempertahankan kebijakan nilai tukarnya. Kondisi ini telah semakin

4. Grafik tersebut memperlihatkan bahwa nilai tukar yang terjadi di pasar cenderung menempel pada batas bawah rentang intervensi (kecuali sejak pelebaran rentang intervensi terakhir tgl. 11 Juli 1997). Hal ini mencerminkan kuatnya tekanan apresiasi akibat derasnya arus masuk modal. 


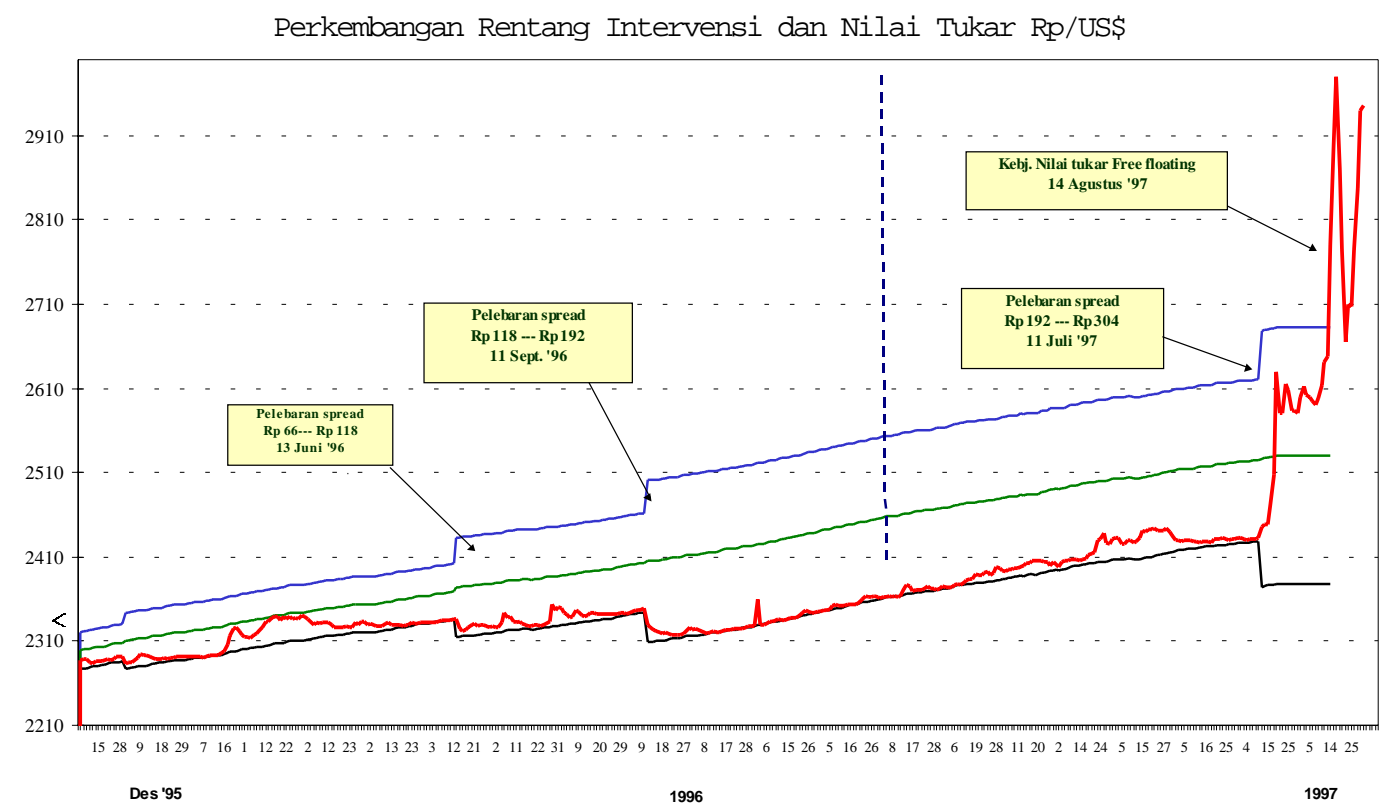

memperkuat tekanan depresiatif terhadap rupiah hingga akhirnya otoritas moneter terpaksa melepaskan rentang intervensi tersebut.

\section{Kebijakan Selama Krisis}

Kebijakan moneter adalah salah satu bagian dari paket kebijakan ekonomi yang diambil dalam rangka menyelesaikan krisis ekonomi yang melanda Indonesia. Paket kebijakan ekonomi yang diterapkan di Indonesia secara garis besar tidak berbeda dengan yang diterapkan oleh negara-negara lain yang memperoleh bantuan IMF. ${ }^{5}$ IMF menawarkan satu paket kebijakan yang mereka sebut langkah-langkah yang bersifat segera (immediate efforts) dalam rangka mengembalikan kepercayaan. Langkah-langkah tersebut mencakup: ${ }^{6}$

- Penerapan sistem nilai tukar mengambang (floating exchange rate).

- Penerapan kebijakan moneter ketat yang bersifat sementara untuk meredam tekanan terhadap neraca pembayaran.

- Tindakan-tindakan terpadu untuk memperbaiki kelemahan-kelemahan sistem keuangan yang mencakup: penutupan dan pengawasan ketat terhadap lembaga-lembaga keuangan yang tidak sehat, rekapitalisasi perbankan, dan peningkatan partisipasi asing dalam sistem keuangan domestik.

5 Rangkuman beberapa pokok kebijakan di bidang moneter dan perbankan yang diterapkan oleh Thailand dan Korea Selatan dapat dilihat dalam Lampiran.

6 Lihat IMF (1998) halaman 2 - 3. 
- Reformasi struktural untuk menghilangkan berbagai penghalang pertumbuhan ekonomi (seperti monopoli, hambatan perdagangan, dan praktek-praktek usaha yang tidak transparan) dan meningkatkan efisiensi fungsi intermediasi keuangan serta kesehatan sistem keuangan di masa mendatang.

- Upaya-upaya untuk membuka kembali atau mempertahankan jalur-jalur sumber dana luar negeri.

- Penerapan kebijakan fiskal yang berhati-hati termasuk dengan membiayai program restrukturisasi sektor keuangan dan mempertahankan/ meningkatkan pengeluaranpengeluaran untuk kepentingan sosial.

Dimasukkannya kebijakan restrukturisasi sektor keuangan sebagai salah satu langkah pertama yang harus diambil oleh negara yang mengalami krisis mencerminkan keyakinan IMF bahwa unsur utama penyebab krisis adalah kelemahan di sektor tersebut. Namun, justru di sinilah fokus kritik yang dialamatkan kepada IMF. Penerapan kebijakan restrukturisasi sektor keuangan di saat kondisi kepercayaan berada pada titik terendah dianggap telah semakin memperparah krisis dan mempersulit penerapan kebijakan moneter. ${ }^{7} \mathrm{Hal}$ ini diperkirakan telah mengakibatkan Indonesia mengalami apa yang dikenal sebagai krisis kembar, yaitu terjadinya krisis perbankan dan neraca pembayaran secara bersamaan. Kondisi ini telah mengakibatkan resep-resep kebijakan ortodoks seperti devaluasi (atau floating rate) atau kebijakan moneter ketat tidak dapat menyelesaikan kedua krisis secara bersamaan.

Secara singkat, penyebab terjadinya krisis kembar dapat dijelaskan sebagai berikut. ${ }^{8}$

- Intervensi valas yang dilakukan oleh otoritas moneter di awal krisis untuk meredam tekanan depresiasi nilai rupiah telah menyedot likuiditas perbankan. Hal ini dapat mengarah kepada credit crunch dan selanjutnya krisis perbankan apabila tidak dilakukan kebijakan sterilisasi. Karena depresiasi nilai rupiah secara tajam akhirnya tidak dapat dihindari, bank-bank yang memiliki kewajiban valas dalam jumlah besar harus menanggung kerugian besar. Kondisi ini diperburuk lagi dengan meningkatnya kredit macet akibat kesulitan yang dihadapi oleh para debitur dalam membayar kewajibannya yang semakin besar seiring dengan tingginya suku bunga.

- Penekanan pada penyelesaian bank bermasalah (khususnya dalam bentuk likuidasi bankbank) sementara kepercayaan masyarakat kepada rupiah dan perbankan nasional sedang berada pada titik terendah telah menimbulkan fenomena flight to arrency . Fenomena ini

7 Lihat misalnya Nananukool (1998) dan Radelet dan Sachs (1998).

8 Uraian lebih mendalam mengenai faktor-faktor yang dapat mendorong timbulnya krisis kembar dapat dilihat dalam Kaminsky dan Reinhart (1996) halaman 1-2. 
telah memaksa otoritas moneter untuk mengeluarkan bantuan likuiditas (BLBI) dalam jumlah besar kepada bank-bank sehingga sangat mengurangi efektivitas kebijakan moneter.

- Di samping kedua alasan di atas, terjadinya krisis perbankan maupun neraca pembayaran secara bersamaan dapat pula disebabkan oleh dampak negatif dari liberalisasi keuangan. Dalam hal ini, liberalisasi sektor keuangan telah mendorong timbulnya bubble economy dan ekspansi kredit yang tidak hati-hati di kalangan perbankan. Distorsi ekonomi mikro - seperti jaminan pemerintah secara implisit atas simpanan masyarakat tampa disertai pengawasan bank yang ketat - yang menimbulkan lonjakan kredit perbankan, pada akhirnya akan berakhir pada kejatuhan sistem perbankan.

Beberapa masalah lain dari sisi kebijakan moneter yang diduga telah memperlambat proses pemulihan kondisi ekonomi di Indonesia adalah:

A. Perubahan arah kebijakan yang diambil akibat adanya tekanan-tekanan untuk mengakomodasi berbagai sasaran yang saling berlawanan (trade-off) telah menurunkan kredibilitas kebijakan pemerintah secara keseluruhan. Kenaikan suku bunga yang diberlakukan oleh otoritas moneter untuk meredam tekanan depresiasi rupiah pada awal krisis ternyata telah menimbulkan kesulitan pada sektor usaha sehingga memaksa otoritas moneter untuk menurunkan suku bunga sejak September 1997. Perubahan arah kebijakan suku bunga ini telah mengurangi kredibilitas pemerintah karena memberikan kesan kepada pasar seolah-olah otoritas moneter tidak konsisten atau raguragu dalam menerapkan kebijakan uang ketat. Penurunan kredibilitas ini mengakibatkan tidak berjalannya proses built-in adjustment yang seharusnya menguatkan nilai tukar.

Perkembangan Kurs (bid side) dan Suku Bunga SBI 1 Bulan

( Juni 1997 - Oktober 1998 )

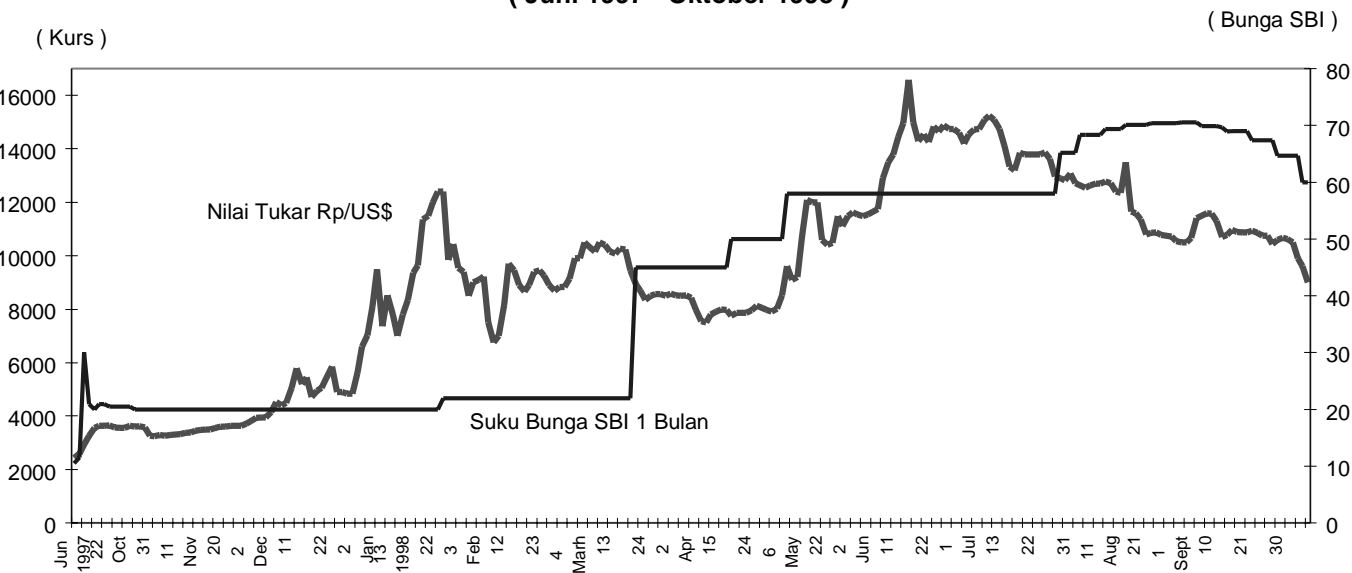


B. Kebijakan yang terlalu responsif terhadap perubahan sentimen pasar diduga telah semakin mendorong tekanan spekulatif. Untuk menstabilkan gejolak nilai tukar dan mengarahkannya ke tingkat yang terjangkau oleh perekonomian nasional, otoritas moneter telah beberapa kali menaikkan tingkat suku bunga SBI. Namun, karena kenaikan-kenaikan suku bunga tersebut pada umumnya diawali atau dipicu oleh tekanan-tekanan depresiatif terhadap rupiah maka timbul kesan bahwa otoritas moneter sangat responsif terhadap tekanan depresiasi (lihat grafik Perkembangan Kurs dan Suku Bunga SBI) . Hal ini diduga telah mendorong para spekulan untuk melontarkan rumor atau sentimen negatif di pasar valas yang seringkali tidak bersifat fundamental dengan harapan otoritas moneter akan menanggapinya dalam bentuk intervensi pasar atau kenaikan suku bunga lebih lanjut.

C. Kombinasi kebijakan fiskal dan moneter ketat di awal krisis telah memperburuk ekspektasi pasar akan prospek ekonomi dan nilai tukar. Meskipun kebijakan fiskal ketat telah dikoreksi oleh pemerintah dan $\mathbb{M} \mathbb{F}$, namun kebijakan tersebut telah sempat memperlemah nilai tukar rupiah ke level yang cukup sulit untuk diturunkan kembali.

D. Penetapan sasaran (indikatif) nilai tukar telah memberikan kesan bahwa otoritas tidak sepenuhnya committed pada sistem nilai tukar mengambang yang diberlakukan sejak 14 Agustus 1997 . Apalagi sasaran indikatif tersedut telah beberapa kali direvisi ke atas (depresiasi) sehingga semakin memperkuat ekspektasi depresiasi sekaligus ekspektasi inflasi di pasar. Kondisi ini diduga telah mendorong semakin kerasnya tekanan-tekanan spekulatif terhadap rupiah sehingga mempersulit upaya memperkuat nilai tukar rupiah dan meredam laju inflasi.

Ada beberapa pelajaran yang dapat diambil dari uraian di atas, yaitu:

- Sulit menemukan suatu kombinasi kebijakan yang tepat untuk mengakomodasi berbagai sasaran secara bersamaan. Dalam hal ini, strategi yang lebih tepat tampaknya adalah dengan memberikan prioritas utama pada suatu sasaran akhir.

- Krisis ekonomi Indonesia yang multidimensional telah menimbulkan konflik antarkebijakan sehingga kinerja masing-masing kebijakan menjadi tidak optimal.

- Kebijakan moneter tidak akan bekerja secara efektif apabila tidak terdapat kepercayaan kepada sistem perbankan domestik.

Oleh karena itu, sembari mempertajam prioritas kebijakan dan meneruskan upaya penyehatan perbankan nasional agar kepercayaan masyarakat cepat pulih, otoritas moneter harus terus berupaya mencari cara guna memperbaiki efektivitas kebijakan moneter. Salah satu upaya tersebut adalah dengan memperbaiki sistem lelang SBI. Sebelum tanggal 29 Juli 1998, suku bunga SBI ditentukan oleh Bank Indonesia. Kondisi likuiditas yang ketat serta 
segmentasi di pasar uang antarbank (yang terkait dengan perbedaan tingkat kesehatan antarbank yang sangat mencolok) telah menyebabkan suku bunga PUAB jauh lebih tinggi daripada suku bunga SBI. Bahkan, seiring dengan tingginya laju inflasi, suku bunga SBI secara riil telah menjadi negatif. Akibatnya, lelang SBI tidak mampu menyedot kelebihan likuiditas di pasar uang. Situasi tersebut berubah sejak tanggal 29 Juli 1998 ketika Bank Indonesia menerapkan sistem lelang SBI yang baru. Dalam sistem tersebut, suku bunga SBI sepenuhnya ditentukan pasar sehingga SBI lebih efektif dalam menyerap likuiditas di pasar.

Sementara proses restrukturisasi perbankan masih berjalan, peningkatan efektivitas kebijakan moneter telah berdampak positif terhadap stabilisasi nilai tukar rupiah dan penurunan tekanan inflasi. Perkembangan terakhir juga menunjukkan bahwa sasaran akan lebih cepat tercapai apabila terdapat konsistensi kebijakan dan penugasan suatu kebijakan pada satu prioritas sasaran. Apabila hal ini terus berlanjut, dalam waktu yang tidak terlalu lama diperkirakan otoritas moneter akan memperoleh ruang gerak yang lebih luas untuk menurunkan suku bunga.

\section{Alternatif Strategi Kebijakan Moneter untuk Indonesia}

Uraian sebelumnya adalah hasil retrospeksi atas kombinasi kebijakan yang telah diambil selama ini. Tentunya yang relevan bagi kita sekarang adalah bentuk strategi kebijakan moneter apa yang tepat untuk diterapkan agar ekonomi Indonesia segera keluar dari krisis. Sebagaimana telah disinggung dalam bagian II, pemilihan strategi kebijakan moneter dan nilai tukar yang tepat tergantung kepada tiga faktor, yaitu:

- Jenis tekanan yang dihadapi. Apabila perekonomian mengalami tekanan moneter maka penggunaan patokan suku bunga (atau nilai tukar bagi perekonomian terbuka) adalah yang paling ideal karena fluktuasi permintaan uang yang terjadi akan diakomodasi oleh neraca pembayaran tanpa mengganggu stabilitas harga atau produksi. Sebaliknya, apabila perekonomian menghadapi tekanan riil, sebaiknya menerapkan pengendalian besaran moneter (monetary rules atau money anchor) karena perubahan nilai tukar akan menyesuaikan tingkat pengeluaran luar negeri akan barang-barang domestik dan tingkat pengeluaran domestik akan barang-barang luar negeri - terutama ketika tingkat upah nominal dan harga-harga sulit bergerak turun - sehingga akan menstabilkan pertumbuhan produksi domestik.

- Karakteristik struktur ekonomi suatu negara. Efektivitas pengendalian besaran moneter (money anchor) antara lain tergantung kepada adanya fleksibilitas tingkat upah riil (e.g. tidak ada indeksasi upah nominal) agar perubahan nilai tukar nominal berdampak jangka panjang terhadap tingkat upah riil dan produksi. Efektivitas pengendalian nilai tukar (exchange rate anchor) tergantung kepada derajat mobilitas modal. Pendekatan ini akan 
lebih memberikan hasil yang memuaskan apabila diterapkan di dalam perekonomian yang lebih terbuka - karena stabilitas nilai tukar akan lebih terkait dengan stabilitas harga - dan memiliki sektor tradable yang cukup terdiversifikasi untuk meredam tekanan-tekanan pada industri-industri tertentu.

- Prioritas sasaran ekonomi yang ditetapkan oleh pemerintah khususnya yang berkaitan dengan trade-off antara produksi, inflasi, dan neraca pembayaran. Bagi negara yang menerapkan pengendalian besaran moneter biasanya akan mengalami variabilitas inflasi jangka pendek yang lebih besar (karena tekanan permintaan uang tidak secara otomatis diakomodasi) namun mengalami variabilitas produksi dan neraca pembayaran yang lebih kecil (karena nilai tukar akan menjadi instrumen penyesuai). Di sisi lain, pendekatan pengendalian nilai tukar memberikan keuntungan berupa transparansi kebijakan, yang merupakan insentif bagi disiplin fiskal.

Dengan menggunakan kriteria di atas, uraian berikut akan mencoba mengidentifikasi strategi kebijakan moneter dan nilai tukar yang tepat untuk diterapkan dalam menghadapi krisis di Indonesia.

\section{A. Jangkar Uang Beredar}

Cukup sulit untuk memilah secara akurat jenis tekanan eksternal yang melanda Indonesia. Dari uraian pada bagian III dijelaskan bahwa contagion effect telah menjadi memicu tekanan di neraca pembayaran dalam bentuk derasnya arus modal keluar. Dengan perkataan lain, tekanan dari sisi moneter adalah pemicu krisis ekonomi di Indonesia.

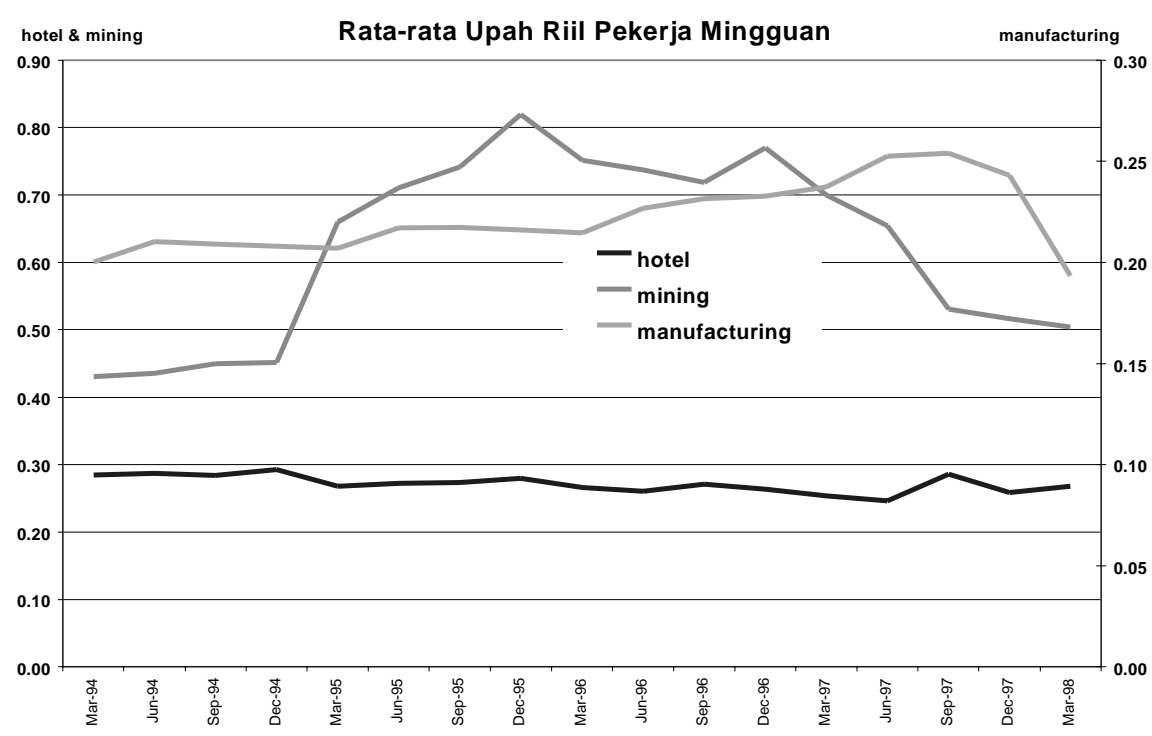


Namun, karena adanya kelemahan di sisi mikro khususnya di sektor perbankan, tekanan dari sisi moneter tersebut secara cepat telah melahirkan gelombang tekanan baru berupa tekanan dari sektor riil, yaitu gangguan pasokan barang akibat terhambatnya impor dan kebangkrutan sektor usaha. Dalam kondisi ini, secara teoritis penerapan strategi jangkar uang beredar dengan sistem nilai tukar mengambang akan mampu mengembalikan stabilitas ekonomi. Apalagi kondisi pasar tenaga kerja tampaknya cukup fleksibel sebagaimana terlihat pada perkembangan tingkat upah riil terutama di sektor manufacturing dan mineral yang cukup responsif terhadap perubahan nilai tukar (lihat Grafik Rata-rata Upah Riil Mingguan) .

Namun, pengalaman beberapa negara yang menerapkan kebijakan floating rate dan diikuti oleh penggunaan base money sebagai nominal anchor (seperti Filipina di tahun 1984) menunjukkan bahwa kebijakan moneter seringkali diterapkan dengan tidak konsisten. Kombinasi kedua kebijakan seringkali mengandung beberapa kelemahan (Houben, 1997) . Pertama, kombinasi floating rate dan sasaran base money diterapkan secara fleksibel sehingga membuat penugasan instrumen kebijakan kepada sasaran-sasaran ekonomi menjadi rancu (ambiguous). Dengan absennya suatu jangkar nominal yang mantap maka terdapat kecenderungan untuk menerapkan sasaran kebijakan moneter berganda seperti: mengendalikan pertumbuhan uang, menstabilkan nilai tukar, memupuk cadangan devisa, menjaga daya saing ekspor, dan menjaga tingkat suku bunga pada level yang mampu mendorong pertumbuhan ekonomi. Sesuai kenyataannya, trade-off di antara berbagai sasaran ini tidak selalu menghasilkan pencapaian sasaran inflasi. Kedua, tanpa komitmen yang jelas terhadap satu sasaran nominal, perekonomian kehilangan suatu piranti untuk mengendalikan ekspektasi inflasi. Ketiga, kebijakan nilai tukar dan intervensi valas seringkali diterapkan secara tidak simetris. Ketika terjadi tekanan apresiasi nilai tukar terutama akibat arus modal masuk otoritas kebanyakan menahan tekanan tersebut dengan membeli devisa sehingga menambah base money (sterilisasi hanya dilakukan secara parsial) . Sebaliknya, ketika terjadi tekanan depresiasi otoritas cenderung membiarkannya dan membatasi penjualan devisa yang seharusnya dapat mendukung nilai tukar dan menyerap base money . Dengan demikian, asimetri kebijakan ini cenderung bias ke arah inflasi.

Untuk kasus Indonesia, adanya sasaran indikatif nilai tukar rupiah dalam paket kebijakan stabilisasi ekonomi Indonesia sementara base money berperan sebagai nominal anchor dikhawatirkan akan menimbulkan permasalahan seperti yang dijelaskan di atas khususnya berupa kemungkinan timbulnya konflik di antara berbagai tujuan kebijakan dan ketiadaan jangkar nominal yang mantap.

Di samping itu, di tengah suasana ketidakpastian, tingkat dan komposisi permintaan akan uang dapat secara mendadak berubah sehingga mengganggu kestabilan velocity dan multiplier. Akibatnya, otoritas moneter akan mengalami kesulitan dalam menyusun proyeksi 
besaran-besaran moneter secara akurat dan dalam mengendalikan jumlah uang beredar. ${ }^{9}$ Dalam situasi ini, strategi jangkar uang beredar mengandung resiko yang cukup besar. Apabila terlalu ketat, kebijakan moneter dapat terlalu mengekang pertumbuhan produksi. Sebaliknya, apabila terlalu longgar akan mempersulit pencapaian sasaran inflasi. Faktor lain yang harus diperhitungkan adalah apabila arah kebijakan ekonomi ke depan berorientasi populis maka penerapan sasaran moneter akan semakin mengalami kesulitan.

\section{B. Jangkar Suku Bunga}

Strategi ini akan cocok diterapkan apabila Indonesia tetap mempertahankan kebijakan nilai tukar mengambang. Namun, beberapa hasil penelitian menunjukkan bahwa kebijakan nilai tukar mengambang bukanlah pilihan yang tepat bagi Indonesia untuk saat ini. Kesimpulan tersebut didasarkan kepada kenyataan bahwa struktur industri kita masih sarat dengan kandungan impor yang tinggi sehingga perubahan nilai tukar sangat berpengaruh terhadap kestabilan tingkat harga (Waluyo dan Siswanto, 1998) . Membiarkan mekanisme pasar menstabilkan nilai tukar dan menghindarkan terulangnya krisis di masa mendatang juga bukan merupakan solusi yang tepat. Hal ini karena meskipun mekanisme pasar ( free floating) dapat meminimalkan kemungkinan terjadinya penyimpangan nilai tukar riil dari nilai ekuilibriumya (real exchange rate misaligrment) namun berkurangnya resiko misalignment itu sendiri tidak menjamin terhindarnya suatu negara dari resiko krisis nilai tukar (Goldfajn, 1997).

\section{Jangkar Nilai Tukar}

Di samping faktor-faktor yang telah disebutkan dalam poin B, faktor-faktor lain yang mendukung penerapan strategi jangkar nilai tukar adalah:

- Perekonomian Indonesia telah berkembang menjadi relatif sangat terbuka. Dalam kondisi ini, nilai tukar telah menjadi indikator harga relatif terpenting dalam perekonomian sehingga menjadi instrumen yang efektif dalam mencapai stabilitas harga.

- Pasar tenaga kerja bersifat fleksibel karena suplai berlimpah dan tidak ada kekakuan tingkat upah yang disebabkan oleh faktor-faktor kelembagaan. Fleksibilitas pasar tenaga kerja, terutama dalam konteks peningkatan produktivitas, akan mengurangi kebutuhan akan penyesuaian nilai tukar nominal.

- Tidak adanya pembatasan devisa telah mempermudah arus keluar masuk modal sehingga mampu mengakomodasi tekanan-tekanan moneter secara otonomus tanpa harus mengandalkan pada fleksibilitas nilai tukar.

9 Beberapa hasil penelitian sebelumnya menunjukkan semakin tidak stabilnya income velocity of money dan money multiplier di Indonesia (Warjiyo dan Zulverdi, 1998). 


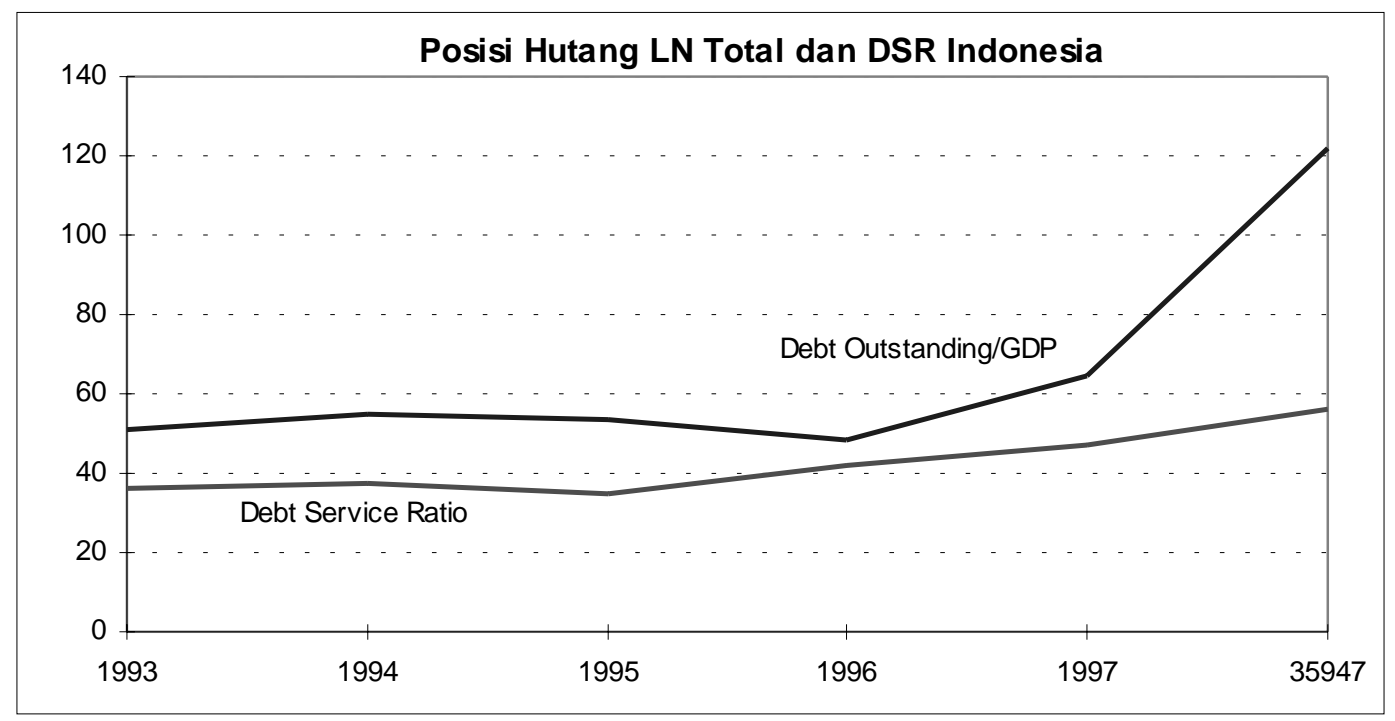

Di sisi lain, terdapat faktor-faktor yang kurang mendukung penerapan strategi jangkar nilai tukar, yaitu:

- Beberapa sisi di neraca pembayaran masih sensitif terhadap tekanan-tekanan eksternal sehingga masih membutuhkan nilai tukar yang fleksibel. Di sisi pembayaran, hutang luar negeri yang sangat besar membuat Indonesia sangat rentan terhadap perubahan suku bunga internasional (lihat Grafik hutang/PDB, DSR). Di samping itu, ketergantungan kepada impor komoditi-komoditi penting khususnya bahan pangan membuat perekonomian sangat sensitif terhadap perubahan harga internasional. Di sisi penerimaan, meskipun diversifikasi produk ekspor telah berlangsung cukup lama namun akses ke pasar modal internasional belum pulih sehingga sistem nilai tukar yang lebih fleksibel masih diperlukan untuk meredam berbagai tekanan eksternal.

- Prospek sisi fiskal masih belum menentu sebagai akibat turunnya potensi pajak dan berkurangnya peranan swasta dalam membiayai pembangunan infrastruktur. Dalam situasi ini, pasar akan meragukan terjaganya disiplin fiskal sekaligus meragukan kredibilitas jangkar nilai tukar.

Di samping itu, terdapat beberapa kelemahan strategi jangkar nilai tukar, yaitu:

- Hilangnya independensi kebijakan moneter dalam meredam tekanan-tekanan riil, baik yang bersifat eksternal maupun internal. Hal ini terutama akan menjadi sangat relevan ketika perekonomian sangat rentan terhadap perubahan sentimen pasar (faktor eksternal, contagion effects) dan gangguan alam dan ketidakstabilan sosial politik (faktor internal) . 
- Apabila nilai tukar riil cenderung mengalami apresiasi yang disebabkan oleh perubahan struktural yang cepat, kemajuan teknologi, liberalisasi perdagangan, dan meningkatnya daya saing negara-negara pesaing, meskipun strategi jangkar nilai tukar kemungkinan besar dapat menurunkan laju inflasi, namun kenaikan harga-harga masih tetap lebih tinggi daripada kenaikan harga-harga di negara-negara partner dagang sehingga lambat laun daya saing produk domestik akan semakin melemah.

D. Jangkar Laju Inflasi

Mengingat rapuhnya perekonomian Indonesia baik terhadap tekanan-tekanan moneter maupun riil, keunggulan jangkar uang beredar maupun nilai tukar menjadi dipertanyakan. Penerapan baik jangkar uang beredar maupun nilai tukar dapat menimbulkan biaya-biaya yang besar dilihat dari sisi pertumbuhan ekonomi dan laju inflasi. Alternatif lain yang dapat diterapkan di Indonesia adalah jangkar laju inflasi. Terdapat beberapa argumentasi yang mendukung penerapan jangkar laju inflasi di Indonesia, yaitu:

- Para pelaku ekonomi, terlebih di masa krisis, membutuhkan suatu jangkar nominal untuk mengarahkan ekspektasi mereka. Mengingat jangkar nilai tukar (fixed exchange rate) sulit diterapkan saat ini sementara disisi lain jumlah uang beredar adalah indikator yang terlalu abtrak bagi para pelaku ekonomi maka jangkar laju inflasi dapat berperan secara langsung dalam mengarahkan ekspektasi laju inflasi.

- Sistem perbankan nasional adalah jalur transmisi kebijakan moneter terpenting. Dalam kondisi normal, sinyal-sinyal kebijakan moneter akan disalurkan melalui sistem perbankan untuk akhirnya mempengaruhi ekpektasi inflasi di masyarakat. Masih sangat rapuhnya kondisi perbankan nasional saat ini dengan sendirinya sangat mengurangi efektifitas kebijakan moneter melalui pengendalian jumlah uang beredar maupun suku bunga. Untuk itu, penggunaan jangkar laju inflasi diharapkan dapat membatasi kelemahan sistem perbankan tersebut.

Agar efektif, penerapan sasaran laju inflasi sebagai jangkar nominal memerlukan penyesuaian kerangka kelembagaan sebagai berikut:

- Pencapaian sasaran laju inflasi harus dijadikan tugas pokok bank sentral.

- Bank sentral perlu meningkatkan transparansi pelaksanaan tugasnya dengan secara eksplisit memberikan argumentasi-argumentasi logis atas berbagai perubahan kebijakan yang mungkin dilakukan. Hal ini dapat dilakukan melalui pemberian informasi yang lengkap mengenai perkembangan terakhir laju inflasi dan hal-hal yang melatarbelakangi penetapan suatu sasaran laju inflasi. Beberapa variabel yang bersifat infommasi (seperti 
pertumbuhan uang beredar, perkembangan nilai tukar) yang konsisten dengan pencapaian sasaran laju inflasi dapat pula dipublikasikan.

- Pelembagaan akuntabilitas bank sentral misalnya melalui pemberian laporan kepada parlemen secara periodik mengenai pencapaian sasaran laju inflasi.

Sekalipun demikian, terdapat beberapa kesulitan dalam menerapkan laju inflasi sebagai jangkar nominal khususnya apabila bank sentral menganggap bahwa laju inflasi berada jauh di luar kendalinya. Hal ini dapat terjadi antara lain karena sulitnya memperkirakan dampak dari tekanan-tekanan moneter dan riil terhadap harga-harga serta sulitnya mengkuantifikasi secara akurat transmisi kebijakan moneter terhadap inflasi di masa perubahan struktural yang cepat. Di samping itu, dengan sulitnya memperkirakan dampak tekanan-tekanan tersebut, penggunaan sasaran laju inflasi secara ketat dapat menimbulkan volatilitas instrumen (khususnya suku bunga) yang sangat tinggi melebihi keuntungan yang diperoleh dari stabilitas inflasi. Pemasalahan ini dapat diatasi melalui penetapan rentang sasaran laju inflasi yang lebih lebar dan dengan mengeluarkan dampak kebijakan pemerintah atau perubahan harga-harga barang tertentu dari penghitungan sasaran inflasi. Namun, rentang sasaran laju inflasi terlalu lebar maka kredibilitas kebijakan bank sentral akan sangat berkurang.

\section{Bagaimana cara membangun kredibilitas?}

Manfaat yang diperoleh dari masing-masing strategi sangat tergantung kepada kredibilitas kebijakan. Di antara beberapa altematif strategi kebijakan moneter di atas, mungkin yang paling sulit adalah membangun kredibilitas kebijakan yang menggunakan pendekatan jangkar uang beredar karena sasaran uang beredar bersifat abstrak. Sekalipun demikian, keyakinan akan suatu sasaran moneter dapat dibangun melalui pemberian sinyal yang transparan mengenai latar belakang penentuan sasaran dan pemberian penjelasan yang logis mengenai berbagai perubahan arah kebijakan.

Dalam kasus jangkar nilai tukar, kredibilitas akan tergantung kepada dua syarat, yaitu:

- Sebelum menetapkan suatu level nilai tukar, laju inflasi harus bergerak pada trend menurun ke arah laju inflasi negara-negara mitra dagang.

- Jumlah cadangan devisa harus meningkat dibandingkan dengan level yang ada sekarang untuk menghadapi tekanan-tekanan spekulasi yang berniat menguji kemampuan otoritas dalam menerapkan jangkar nilai tukar. Hal ini akan cukup sulit dipenuhi selama arus masuk modal dan kepercayaan investor belum pulih kembali.

Kredibilitas jangkar laju inflasi sebagian besar akan ditentukan oleh transparansi kelembagaan dan akuntabilitas bank sentral dalam memenuhi sasaran laju inflasi. Komitmen 
pemerintah secara eksplisit terhadap pencapaian sasaran laju inflasi yang menjadi tanggung jawab bank sentral akan sangat menentukan kredibilitas kebijakan ini.

\section{Penutup}

Berikut beberapa pokok pikiran dan satu rekomendasi kebijakan :

- Kondisi fundamental ekonomi makro Indonesia sebelum krisis memang menunjukkan tekanan-tekanan yang berpotensi untuk menjadi krisis.

- Terdapat indikasi adanya ketidaktepatan kebijakan atau kombinasi kebijakan yang diambil dalam periode sebelum, di awal, dan selama krisis yang diduga telah menjadi faktor yang memperburuk krisis nilai tukar di Indonesia.

- Ketidaktepatan kebijakan tersebut sebagian besar disebabkan oleh kompleksitas masalah yang dihadapi oleh perekonomian Indonesia sehingga seringkali terjadi benturan di antara berbagai kebijakan.

- Upaya stabilisasi ekonomi di dalam konteks sistem nilai tukar mengambang penuh tampaknya tidak cocok untuk diterapkan di Indonesia.

- Penggunaan suatu jangkar nominal, baik berupa jangkar nilai tukar atau jangkar laju inflasi, tampaknya layak untuk dipelajari lebih dalam kemungkinan penerapannya di Indonesia. Mengingat masih rapuhnya sistem perbankan nasional sebagai jalur transmisi kebijakan moneter terpenting serta masih sangat rentannya perekonomian Indonesia terhadap tekanan-tekanan eksternal, suatu sistem nilai tukar yang agak fleksibel tampaknya lebih cocok untuk dikombinasikan dengan strategi jangkar inflasi.

\section{Daftar Pustaka}

ADB Institute, Asia: Responding to Crisis, 1998.

Bank Indonesia, Report for the Financial Year 1997/98, Jakarta, 1998.

Bank Negara Malaysia, Measures to Regain Monetary Independence, Kuala Lumpur, September 1998.

Exchange Control Notices, Kuala Lumpur, 1998.

Goldfajn, Ilan, dan Rodrigo O. Valdes, Are Currency Crisis Predictable?, IMF Working Paper No. 97/159, Washington, D.C., 1997.

Harberger, Arnold C., Notes on the Indonesian Crisis, An Aide-memoire on a series of meeting in Jakarta, UCLA, September 1998. 
The Anatomy of Crisis, Keynote Address at a conference on sustaining economic growth in Indonesia, UCLA, Desember 1997.

Houben, Aerdt C.F.J., Exchange Rate Policy and Monetary Strategy Options in the Philippines - the Search for Stability and Sustainability, IMF Paper on Policy Analysis and Assessment, PPAA/97/4, Washington, D.C., 1997.

IMF, World Economic Outlook, May Edition, Washington, D.C., 1995.

The $\mathbb{M} \mathbf{F}^{\prime}$ s Response to the Asian Crisis, External Relations Department, Washington, D.C., Juli 1998.

Kaminsky, Graciela L., Currency and Banking Crisis: the Early Wamings of Distress, Washington, D.C., 1998.

Kaminsky, Graciela L., dan Carmen M. Reinhart, The Twin Crisis: the Causes of Banking and Balance of Payments Problems, Washington, D.C., 1996.

Krugman, Paul, External Shocks and Domestic Policy Responses, dalam The Open Economy: Tools for Policymakers in Developing Countries, edited by Rudiger Dornbusch and F. Leslie C.H. Helmers, p. 54-79, Oxford University Press, New York, 1995.

Currency Crises, downloaded at http://www.mit.edu/krugman. October.1998.

McNelis, Paul D., Money Demand, Financial Distress, and Exchange Rate Uncertainty in Indonesia, A Research Paper written at Bank Indonesia, unpublished, Jakarta, April 1998.

Financial Liberalization, Share Price Volatility and Monetary Policy: The Experience of Indonesia, A Research Paper written at Bank Indonesia, unpublished, Jakarta, Jili 1994.

Meigs, James, Lessons for Asia from Mexico, The Cato Journal Vol 17 No.3, 1998.

Nananukool, Surasak, Learning from the Asia Currency Curency Crisis - An Insider View from Thailand, A paper presented at the Carnegie Mellon University, Graduate School of Industrial Administration, March 1998.

Paderenga, Cayetano, Currency Crisis and Policy Response: The ASEAN and Philippine Case, September 1998.

Pasadilla, Gloria, What Make Countries Vulnarable to Currency Crisis ?, ADB Institute Seminar-Workshop on Asia's Financial Crisis: Lessons and Policy Responses, September 1998. 
Poole, William, Optimal Choice of Monetary Policy Instruments in A Simple Stochastic Macro Model, Quarterly Journal of Economics, Vol. 84, hal. 197 - 216, Mei 1970.

Radelet, Steven, dan Jeffrey Sachs, The Onset of the East Asian Financial Crisis, 1998.

Waluyo, Dody B., dan Benny Siswanto, Peranan Kebijakan Nilai Tukar dalam Era Deregulasi dan Gldbalisasi, Buletin Ekonomi Moneter dan Perbankan, Vol. 1, No. 1, Juli 1998.

Warjiyo, Perry, dan Doddy Zulverdi, Penggunaan Suku Bunga sebagai Sasaran Operasional Kebijakan Moneter di Indonesia, Buletin Ekonomi Moneter dan Perbankan, Vol. 1, Nb. 1, Jli 1998.

World Bank, Indonesia in Crisis: A Macroeconomic Update, Washington, D.C., 1998.

Lampiran

Langkah-langkah Kebijakan di Bidang Moneter dan Perbankan yang Diambil oleh Thailand dan Korea Selatan

\section{Thailand}

Diawali dengan kinerja yang buruk dari lembaga-lembaga keuangan domestik dan besarnya hutang luar negeri yang akan jatuh tempo dalam tahun 1997, nilai baht mendapat tekanan yang besar dari pasar (spekulan) agar terdepresiasi. Terpuruknya nilai baht pada gilirannya memperparah keadaan lembaga keuangan yang sebagian mempunyai pinjaman luar negeri yang tidak di- hedged.Bubble economy yang antara lain ditunjukkan oleh besarnya kredit pada sektor properti yang dibiayai oleh bank dengan sumber dana hutang luar negeri turut memberikan andil atas kondisi tersebut.

Menghadapi masalah ini, pemerintah Thailand terpaksa mengalihkan sistem nilai tukar menjadi sistem mengambang dan meminta kepada IMF untuk memberikan paket pinjaman guna menghadapi krisis tersebut. Paket pinjaman tersebut disertai dengan program restrukturisasi sektor keuangan, peningkatan tabungan pemerintah dengan menaikkan pajak, perbaikan transaksi berjalan, dan pengetatan moneter. Namun beberapa pengamat menilai paket tersebut tidak memadai karena: pertama, dari sisi jumlah bantuan yang dianggap terlalu kecil bagi ukuran Thailand yang telah banyak kehilangan cadangan devisa untuk mempertahankan nilai baht, dan yang kedua adalah tidak adanya rekomendasi yang memadai untuk menyelesaikan masalah hutang sektor swasta yang akan jatuh tempo tahun 1997 dan berpotensi untuk menekan nilai baht. 
A. Kebijakan Moneter

Peningkatan suku bunga yang dilakukan untuk menarik arus modal masuk telah menyebabkan mandeknya fungsi bank-bank komersial sehingga tekanan-tekanan baik sebagai akibat penutupan perusahaan keuangan, peningkatan standar perbankan, maupun dari kebijakan suku bunga tinggi telah menjadikan kondisi perbankan menjadi semakin terpojok. Kondisi ini telah mengakibatkan krisis likuiditas di Thailand pada akhimya mengganggu kegiatan dunia usaha sehingga peluang peningkatan ekspor sektor industri yang seharusnya terjadi karena depresiasi nilai baht menjadi hilang. Gambaran umum kinerja ekspor yang tidak menguntungkan ini masih terselamatkan oleh ekspor dari sektor pertanian yang mengalami peningkatan karena naiknya harga produk-produk pertanian di pasar intemasional.

Pada bulan Mei 1998 dalam usahanya untuk menghidupkan kembali sektor industri, Thailand telah bersepakat dengan IMF untuk menurunkan tingkat bunga dan meningkatkan pertumbuhan jumlah uang beredarnya seiring dengan meningkatnya permintaan uang.

\section{B. Kebijakan Perbankan}

Diawali dengan pendirian FRA (Financial Sector Restructuring Agency) yang bertanggung jawab atas rencana rehabilitasi perusahaan keuangan dan assetnya dan pendirian AMC (Asset Management Corporation) yang mengurusi dan menjual asset yang tidak sehat, Thailand melakukan penyehatan sistem keuangan di Thailand, antara lain dengan menutup 58 perusahaan keuangan, dengan dasar kriteria kondisi likuiditas perusahaan yang bersangkutan. Dari sisi upaya penyehatan sistem keuangan hal tersebut memang baik, hanya saja dalam jangka pendek penutupan perusahaan keuangan yang dilakukan ini telah menimbulkan berbagai masalah dan menyebabkan semakin merosotnya perekonomian. Timbulnya berbagai masalah tersebut disebabkan oleh: pertama adanya keterkaitan yang erat antara perusahaan keuangan dengan sektor usaha yang lain sehingga penutupan itu mengakibatkan macetnya kegiatan usaha yang bertumpu pada pinjaman dari perusahaan keuangan; kedua karena sumber dana dari perusahaan keuangan adalah dari bank, maka penutupan itu berakibat pada peningkatan non-performing loan bank-bank yang mempunyai konsekuensi pada peningkatan cadangan aktiva yang pada gilirannya menghambat ekspansi kredit dari perbankan; ketiga adalah masalah kriteria penutupan yang dipakai di mana banyak perusahaan keuangan yang mempunyai modal lebih besar dari standar internasional tentang rasio kecukupan modal, ternyata ditutup dengan alasan jumlah pinjaman dari bank sudah melebihi modal perusahaan itu. Langkah penutupan perusahaan keuangan tersebut dilanjutkan dengan meningkatkan secara bertahap peraturan perbankan yang menyangkut akuntansi perbankan, keterbukaan, peningkatan CAR dan pengetatan kriteria non performing loan dan penyediaan cadangan penyisihan aktiva. 


\section{Korea Selatan}

Kebijakan pemerintah Korea Selatan dalam menyikapi krisis yang terjadi tidak berbeda jauh dengan yang dilakukan oleh negara-negara lain yang terkena krisis dan mendapatkan bantuan dari IMF. Kebijakan tersebut pada umumnya mengarah pada liberalisasi perekonomian dalam rangka meningkatkan efisiensi dan pengetatan kegiatan ekonomi dalam jangka pendek. Secara garis besar kebijakan-kebijakan yang diambil oleh Korea Selatan antara lain adalah sebagai berikut:

\section{A. Kebijakan Moneter dan Nilai Tukar}

Seperti halnya negara lain yang mengalami krisis nilai tukar, Korea Selatan telah melakukan kebijakan uang ketat dalam rangka meredam gejolak nilai tukarnya. Kebijakan ini dilakukan bersamaan dengan restrukturisasi perbankan, liberalisasi pasar modal dan peningkatan transparansi perusahaan-perusahaan. Selain itu, dalam rangka mengeliminir kelemahan dari sistem kurs yang lama sejak bulan Desember 1997 Korea telah mengambangkan nilai tukar won ( free floating) dan menghilangkan daily exchange rate band. Disetujuinya restrukturisasi hutang luar negeri perbankan jangka pendek sebesar US\$ 22 miliar dan diterbitkannya obligasi pemerintah dalam denominasi US\$ di luar negeri turut mendukung upaya stabilisasi nilai won. Perkembangan lain yang terjadi adalah adanya pergeseran struktural dimana Korea Selatan sekarang mengalami surplus transaksi berjalan. Hal ini disebabkan karena menurunnya impor sebagai akibat dari terkontraksinya perekonomian dan juga meningkatnya daya saing barang produksi Korea akibat dari terdepresiasinya nilai won.

\section{B. Kebijakan Perbankan}

Usaha pengembalian kepercayaan masyarakat terhadap perbankan dilakukan Pemerintah dengan cara:

1. Dalam periode Januari s.d. April 1998 Pemerintah menutup 14 merchant bank dan mewajibkan merchant bank yang lain untuk memenuhi CAR sebesar 6\% di bulan April 1998 dan 8\% akhir Juni 1999. Di samping itu, Pemerintah mendirikan Lembaga Perantara Merchant Bank untuk membayar deposito nasabah, mengambil alih, mengumpulkan dan melikuidasi asset merchant bank yang ditutup.

2 Memberikan bantuan likuiditas (dalam won) kepada bank-bank yang mempunyai kaitan dengan merchant bank yang ditutup.

3. Bank-bank yang tidak memenuhi batas minimal CAR diwajibkan untuk menyampaikan rencana rekapitalisasi kepada Otoritas Pengawas Perbankan. 
4 Pengkonsolidasian pelaksanaan deposit insurance oleh Korean Deposit Insurance Cooperation (KDIC) serta memperluas cakupan kewajiban institusi (comercial, merchant dan institusi keuangan lain) yang dijamin dalam deposit insurance.

5. Pendirian Supervisory Commission yang bertanggung jawab atas pengawasan dan restrukturisasi bank dan lembaga keuangan bukan bank.

Upaya-upaya tersebut kemudian dilanjutkan dengan mengeluarkan kebijakankebijakan tambahan (Agustus 1998), antara lain:

1. Memberikan bantuan keuangan kepada Bank of Korea, melakukan penyertaan modal pada bank, dan memberikan special funding facility kepada merchant bank yang hampir bangkrut sebesar lebih dari 50\% modal bank yang bersangkutan.

2 Menyediakan special fund yang dirancang dalam Korea Asset Management Corporation $(\mathrm{KAMC})$, yang merupakan suatu wadah dimana bank-bank dapat menjual non-performing asset-nya.

3. Pemerintah memberikan jaminan atas hutang-hutang luar negeri lembaga keuangan Korea Selatan, termasuk bank komersial dan merchant bank.

C. Kebijakan Pasar Modal dan Investasi Asing

Di bidang pasar modal dan investasi asing, Pemerintah Korea Selatan menempuh kebijakan-kebijakan sebagai berikut:

1. Peningkatan batas maksimal kepemilikan asing atas perusahaan publik Korea Selatan secara keseluruhan dari 26\% menjadi 50\%, dan secara individual dari 7\% menjadi 50\%; menghilangkan pembatasan investasi asing pada non-guaranteed bond yang dikeluarkan oleh perusahaan kecil dan menengah; mengijinkan investasi asing dalam pasar guaranteed conporate bond market (maturity > 3 tahun) dengan batas maksimal 10\% untuk individual dan secara keseluruhan maksimal 30\% (11 Desember 1997).

2. Menaikkan batas maksimal investasi asing di non-guaranteed conporate (convertible) bond dari 30 \% menjadi 50\% (12 Desember 1997).

3. Mengijinkan asing untuk melakukan investasi pada government bond dan special bond sampai dengan 30\% dan menghilangkan pembatasan investasi asing individual pada conporate bond (23 Desember 1997).

4 Memperlunak pembatasan kepemilikan asing di bank komersial dan menghapus maksimal kepemilikan sebesar 4\%. Penguasaan modal bank oleh bank asing tidak dibatasi, akan tetapi harus bertahap, tahap pertama 10\%, tahap kedua 25\%, dan 31\% 
pada tahap ketiga. Kepemilikan oleh individu domestik di atas 4\% diperbolehkan sepanjang pihak bank asing juga mempunyai kepemilikan yang sama atau lebih besar (29 Desember 1997).

5 Penghapusan semua batas maksimal investasi asing pada pasar government bond, special bond, dan conporate bond. Memperketat aturan pinjaman luar negeri yang jatuh tempo di atas 3 tahun (30 Desember 1997).

6 Menghilangkan restriksi pinjaman luar negeri perusahaan sampai dengan 2 juta USD untuk perusahaan modal ventura. Pemerintah mengijinkan lembaga nonkeuangan mengeluarkan surat hutang di pasar uang kepada pihak asing tanpa batas jumlah (16 Februari 1998).

7. Bank Asing dan Broker diijinkan mendirikan cabang-cabang. 